\title{
Predictive and Prognostic Biomarkers for Lung Cancer Bone Metastasis and Their Therapeutic Value
}

\author{
Xupeng Chai ${ }^{1,2 \dagger}$, Eloy Yinwang ${ }^{1,2 \dagger}$, Zenan Wang ${ }^{1,2 \dagger}$, Zhan Wang ${ }^{1,2}$, Yucheng Xue ${ }^{1,2}$, \\ Binghao $\mathrm{Li}^{1,2}$, Hao Zhou ${ }^{1,2}$, Wenkan Zhang ${ }^{1,2}$, Shengdong Wang ${ }^{1,2}$, Yongxing Zhang ${ }^{1,2}$, \\ Hengyuan $\mathrm{Li}^{1,2}$, Haochen Mou ${ }^{1,2}$, Lingling Sun ${ }^{1,2}$, Hao Qu ${ }^{1,2}$, Fangqian Wang ${ }^{1,2}$, \\ Zengjie Zhang ${ }^{1,2}$, Tao Chen ${ }^{1,2}$ and Zhaoming Ye ${ }^{1,2 *}$ \\ ${ }^{1}$ Department of Orthopedics, Musculoskeletal Tumor Center, The Second Affiliated Hospital of Zhejiang University School of
Medicine, Hangzhou, China, ${ }^{2}$ Institute of Orthopedic Research, Zhejiang University, Hangzhou, China
}

\section{OPEN ACCESS}

Edited by:

Giuseppe Giaccone,

Cornell University, United States

Reviewed by:

Qian Zhao,

Sichuan University, China

Nadia Rucci,

University of L'Aquila, Italy

*Correspondence:

Zhaoming Ye

yezhaoming@zju.edu.cn

${ }^{\text {t}}$ These authors have contributed equally to this work

Specialty section: This article was submitted to

Cancer Molecular Targets and Therapeutics,

a section of the journal

Frontiers in Oncology

Received: 09 April 2021 Accepted: 30 August 2021 Published: 14 October 2021

Citation:

Chai $X$, Yinwang $E$, Wang $Z$, Wang $Z$,

Xue Y, Li B, Zhou H, Zhang W, Wang S, Zhang Y, Li H, Mou H, Sun L, Qu H, Wang F, Zhang Z, Chen T and Ye Z (2021) Predictive and Prognostic

Biomarkers for Lung Cancer Bone Metastasis and Their Therapeutic Value.

Front. Oncol. 11:692788. doi: 10.3389/fonc. 2021.692788
Lung cancer is the leading cause of cancer-related death worldwide. Bone metastasis, which usually accompanies severe skeletal-related events, is the most common site for tumor distant dissemination and detected in more than one-third of patients with advanced lung cancer. Biopsy and imaging play critical roles in the diagnosis of bone metastasis; however, these approaches are characterized by evident limitations. Recently, studies regarding potential biomarkers in the serum, urine, and tumor tissue, were performed to predict the bone metastases and prognosis in patients with lung cancer. In this review, we summarize the findings of recent clinical research studies on biomarkers detected in samples obtained from patients with lung cancer bone metastasis. These markers include the following: (1) bone resorption-associated markers, such as $\mathrm{N}$-terminal telopeptide (NTx)/C-terminal telopeptide (CTx), C-terminal telopeptide of type I collagen (CTX-I), tartrate-resistant acid phosphatase isoform 5b (TRACP-5b), pyridinoline (PYD), and parathyroid hormone related peptide (PTHrP); (2) bone formation-associated markers, including total serum alkaline phosphatase (ALP)/bone specific alkaline phosphatase $(\mathrm{BAP})$, osteopontin (OP), osteocalcin (OS), amino-terminal extension propeptide of type I procollagen/carboxy-terminal extension propeptide of type I procollagen (PICP/PINP); (3) signaling markers, including epidermal growth factor receptor/Kirsten rat sarcoma/ anaplastic lymphoma kinase (EGFR/KRAS/ALK), receptor activator of nuclear factor $\kappa B$ ligand/receptor activator of nuclear factor $\mathrm{\kappa B} /$ osteoprotegerin (RANKL/RANK/OPG), C-X-C motif chemokine ligand 12/C-X-C motif chemokine receptor 4 (CXCL12/CXCR4), complement component 5 a receptor (C5AR); and (4) other potential markers, such as calcium sensing receptor (CASR), bone sialoprotein (BSP), bone morphogenetic protein 2 (BMP2), cytokeratin 19 fragment/carcinoembryonic antigen (CYFRA/CEA), tissue factor, cell-free DNA, long non-coding RNA, and microRNA. The prognostic value of these markers is also investigated. Furthermore, we listed some clinical trials targeting hotspot biomarkers in advanced lung cancer referring for their therapeutic effects.

Keywords: predictive/prognostic biomarkers, lung cancer, bone metastasis, bone formation-associated markers, bone resorption-associated markers, bone metastasis-associated signaling markers 


\section{INTRODUCTION}

Lung cancer, comprising non-small-cell lung cancer (NSCLC) and small-cell lung cancer (SCLC), is the leading cause of cancerrelated death worldwide, with approximately 1.6 million deaths reported annually (1). Approximately $36 \%$ of all lung cancers and $54.5 \%$ of the stage II-IIIA NSCLC cases showed postoperative recurrence or metastasis. Bone metastasis, which is the most common site for tumor distant dissemination, is detected in more than one-third of patients with advanced lung cancer $(2,3)$. Patients with bone metastases experience complications, including severe bone pain, pathological fractures, spinal cord and nerve compression, and other skeletal-related events, which significantly reduce patient quality of life $(2,4)$. According to the guidelines of the European Society for Medical Oncology and several clinical studies, use of bisphosphonates (e.g., zoledronic acid) or antireceptor activator of nuclear factor $\mathrm{\kappa B}(\mathrm{NF}-\mathrm{\kappa B})$ ligand (antiRANKL) monoclonal antibody (e.g., denosumab) is recommended for the treatment of lung cancer patients with bone metastasis (5-9).

The detection of lesions in patients at early disease stages before the occurrence of distinct clinical symptoms is challenging. This delayed diagnosis shortens the optimal treatment period. Therefore, early diagnosis of bone metastasis at the initial staging work-up could lead to markedly improved clinical outcomes. Thus far, the most accurate method for the detection of bone metastasis is bone marrow biopsy. Moreover, imaging diagnostic methods, including X-ray, computed tomography, magnetic resonance imaging, technetium $99 \mathrm{~m}-$ methyl diphosphonate $\left({ }^{99 \mathrm{~m}} \mathrm{Tc}-\mathrm{MDP}\right)$ bone scan, and ${ }^{18} \mathrm{~F}$ fluorodeoxyglucose positron emission tomography/computed tomography play critical roles $(10,11)$. However, the clinical application of these procedures is limited due to their low specificity, invasive operation, complex process, and high costs. Thus, other indirect markers are unavoidably required for predicting lung cancer bone metastasis in addition to its prognosis.

It is widely acknowledged that adenocarcinoma, pathological stage III disease, and advanced age are significantly related to a high risk of bone metastasis (12-14). Moreover, lymph node metastasis has been associated with higher odds of multiorgan metastases and a worse overall survival (OS) (15). Programmed cell death 1 ligand 1 (PD-L1) immunochemistry is commonly used as a prognostic biomarker of immune checkpoint inhibitor for clinical decision making. Nevertheless, some researchers suggest that the usefulness of PD-L1 expression is controversial $(16-18)$. Moreover, the tumor mutational burden is measured by whole exome and next-generation sequencing to predict the clinical outcome after treatment with immune checkpoint inhibitor, as well as bone metastasis (19). Nevertheless, these factors provide limited information. Thus, it is important to investigate novel methodologies and therapeutics that would increase the proportion of patients responding to such treatments, while simultaneously improving their side effect profile.
Studies on potential markers in the serum, urine, and tumor tissue were undertaken to predict the bone metastases in patients with NSCLC. Some of these markers are stable and easy to detect, and potentially helpful in disease classification, diagnosis, and treatment.

In this review, we summarize the findings of recent clinical research studies on markers detected in samples obtained from patients with lung cancer, and analyze their capacity for the prediction of treatment response and prognosis of bone metastasis. For a logical classification, these markers are divided into bone resorption-associated markers, bone formation-associated markers, bone metastasis-associated signaling markers, and others (20). The overall concept pictureof lung cancer bone metastasis is showed in Figure 1.

\section{OSTEOCALST- AND BONE RESORPTION- ASSOCIATED BIOMARKERS}

The components of the bone microenvironment, including osteocytes, immune cells, and bone matrix, play critical roles in bone metabolism and tumor cell seeding, dormancy, and growth (21). The interaction between osteoclasts and osteoblasts promotes bone degradation through the release of several factors. Disseminated lung cancer cells activate osteoclasts around metastatic foci, which facilitate expansion in the mineralized matrix (22). During these processes, the rate of resorption can also be quantified through several bone resorption markers, which are described below.

\section{$\mathrm{N}$-terminal Telopeptide (NTx) and C-Terminal Telopeptide (CTx)}

Type I collagen is the principal collagen in the skeletal system, accounting for approximately $90 \%$ of the organic chemical constituents of bone. NTx and CTx are the degradation products of collagen which are released into blood when bone is absorbed, and subsequently collected in urine after kidney drainage $(23,24)$. Studies performed by Izumi et al. and Chung et al. indicated that urinary NTx plays a significant role in the diagnosis of patients with bone-metastatic lung cancer $(25,26)$. In addition, the levels of serum NTx were increased in patients with NSCLC as well as other solid tumors with bone metastasis $(23,27)$. Bayrak et al. $(28)$ demonstrated that, at the threshold value of $25.69 \mathrm{nmol}$ bone collagen equivalents (BCE), the sensitivity of serum NTx was $90.42 \%$ and the specificity was $43.4 \%$. Kaira et al. (29) revealed that normalization of elevated urinary NTx at 1 month after chemotherapy was correlated with the therapeutic response of patients with bone-metastatic lung cancer. Moreover, Zhang et al. (30) analyzed 1,279 patients and revealed that serum concentration of NTx was significantly high in the Chinese population with bone metastasis from solid tumors including lung cancer. Similarly, the measurement of $\mathrm{CTx}$ is considered very helpful for the complementary diagnosis of bone metastasis from lung tumor (31-33). However, some researches indicated that the levels of CTx were not significantly different between patients and healthy individuals (28). These 


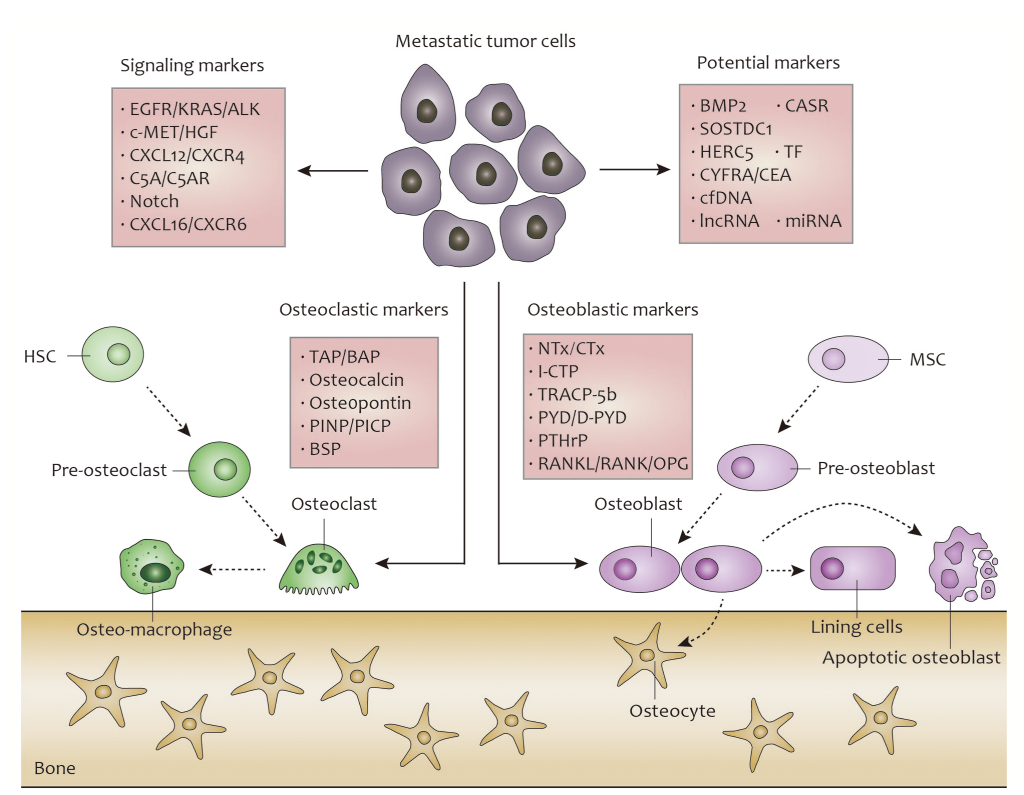

FIGURE 1 | Overall concept picture about biomarkers during the progress of lung cancer bone metastasis.

inconsistent results may be attributed to the effects of diets or injuries on the levels of CTx. Therefore, both NTx and CTx are beneficial in detecting bone metastasis in lung cancer and worth further exploring.

\section{C-Terminal Telopeptide of Type I Collagen (I-CTP)}

Pyridinoline (PYD) cross-linked I-CTP is a metabolite released during the degradation of type I collagen. It is recognized as one of the most accurate markers for bone metastasis. In 2005, Yokoyama et al. (34) conducted a clinical research study of 87 patients with primary lung cancer, showing that serum I-CTP was significantly higher in patients with bone metastasis than those without. The most efficient cut-off value for I-CTP computed in this study was $6.4 \mathrm{ng} / \mathrm{ml}$. A study performed by Tanaka et al. (35) in 2013, which included a larger number of patients, yielded similar results. Charpko et al. (36) utilized the ${ }^{99 m}$ Tc-MDP scan technique to directly demonstrate the correlation between serum I-CTP and the extent of metastatic disease in bone. Kong et al. (37) compared the clinical effect of serum $\beta$-type collagen carboxy-terminal peptide and I-CTP in 126 patients, demonstrating that the latter has higher sensitivity and accuracy with a similiar receiver operating characteristic curve [area under the curve (38)] value. Tang et al. (33) combined tartrate-resistant acid phosphatase isoform-5b (TRACP-5b) and I-CTP as prognostic factors, revealing an elevated AUC of 0.895 compared with that of each factor alone $(\mathrm{p}<0.0001)$; the cut-off values were $7.6 \mathrm{U} / 1$ and $8.4 \mathrm{U} / \mathrm{l}$, respectively. These studies showed that I-CTP may be a reliable marker and assessment using several markers can be more beneficial in the prediction of bone metastasis.

\section{TRACP-5b}

TRACP-5b is an enzyme secreted mainly by activated osteoclasts, thus reflecting the enrichment and vitality of osteoclasts. Its serum levels reflect the degree of osteolytic bone metastasis and the tumor burden within the bone milieu (39). Moreover, this enzyme responds rapidly and significantly to anti-resorptive treatment and is minimally affected by diet and renal or hepatic disease compared with NTx and CTx. These features render TRACP-5b to be a bone-specific assessment factor. Studies have demonstrated that the levels of TRACP-5b are significantly higher in breast cancer and prostate cancer with bone metastasis $(40,41)$. Notably, in patients with lung cancer bone metastasis, some clinical research has produced controversial results regarding its accuracy $(32,33,42-44)$. In clinical cases, the elevation of TRACP-5b can be caused by physiological processes, such as osteoporosis and hyperparathyroidism. Thus, other markers should be considered in combination with TRACP-5b for prediction.

\section{Pyridinoline(PYD) Cross-Linked and Deoxypyridinoline (D-PYD) Cross-Linked}

Serum PYD cross-linked is a cross-linked amino acid appearing in the collagen composition of numerous tissues, which could be deoxidized into D-PYD cross-linked. PYD and D-PYD are released into the circulation as a result of osteoclastic degradation of the bone matrix $(45,46)$. Ebert et al. (42) stated that the levels of serum PYD and D-PYD were higher $(\mathrm{p}<0.01)$ in patients with bone metastasis than those with benign lung diseases. The sensitivity (specificity) values were 91.8\% (24.1\%) and $83.7 \%$ (34.5\%), respectively. Furthermore, Dane et al. (47) revealed that the high levels of urinary D-PYD may be an early 
sign of metastasis in patients without bone abnormality assessed by imaging techniques. This is because D-PYD is not internally metabolized, but excreted in the urine. Hence, the measurement of D-PYD in urine is of great importance in monitoring bone resorption.

\section{Parathyroid Hormone-Related Peptide (PTHrP)}

PTHrP, secreted by malignant tumor cells, acts as a potent stimulator of osteoclastic bone resorption and may induce hypercalcemia (48). Miki et al. (49) designed a series of studies with anti-PTHrP neutralizing antibody. They found that PTHrP played an essential role in bone metastasis, but not visceral metastases, in SCLC, indicating to some extent the specificity of PTHrP. Katseli et al. (50) collected the circulating tumor cells in peripheral blood and concluded that the mRNA levels of PTHrP correlated positively with lung cancer stage, presence of bone metastasis, and squamous cell carcinoma. Deng et al. (51) detected the upregulated expression of PTHrP in bone metastasis sites of NSCLC by reverse transcription-polymerase chain reaction(RT-PCR) and immunohistochemistry. Teng et al. (52) constructed a novel model, including PTHrP, for the early identification of lung cancer bone metastasis. This model included 205 patients, and the average predictive time for the occurrence of bone metastasis was 9.46 months (shorter than that of bone scan diagnosis). Moreover, the response to some osteoclast-targeted therapies, including erlotinib and reveromycin A, could also be estimated by the serum levels of PTHrP $(53,54)$.

\section{RANKL/RANK/Osteoprotegerin (RANKL/ RANK/OPG) System}

The RANKL/RANK/OPG pathway is a vital regulator of bone metabolism in normal and pathological conditions, such as the "Vicious Cycle" (55). RANK is a surface receptor specifically expressed on osteoclasts and their progenitors. It is activated by binding to RANKL expressed on the surface of osteoblasts and stromal cells, with the assistance of macrophage-colony stimulating factor (M-CSF) (56). The RANK/RANKL interaction subsequently activates transcription factors, such as $\mathrm{NF}-\kappa \mathrm{B}$, and eventually increases the number of activated osteoclasts (57). OPG, a decoy receptor secreted by osteoblasts and stromal cells, inhibits the positive effects of RANKL on osteoclasts by preventing the RANKL/RANK interaction. This leads to hindrance of osteoclastogenesis and bone resorption (58).

The RANKL/RANK/OPG axis has been used in the prediction of bone metastasis. Karapanagiotou et al. (43) demonstrated that increased serum levels of RANKL were detected in NSCLC patients with bone metastases, while increased levels of OPG were observed in all patients with lung cancer. Terpos et al. (44) revealed an unusually low serum TRACP-5b/RANKL ratio in patients with existing or subsequent metastasis. Santini et al. (59) performed an immunohistochemical analysis of tumor tissues collected from 74 patients. The results displayed that $89 \%$ of the patients with bone metastasis were RANK-positive, and $59.5 \%$ of patients showed $>50 \%$ positive tumor cells. Moreover, there was no significant difference noted in the expression of RANK between primary tumors and metastases (59). According to these research studies, the RANK/RANKL pathway shows great stability and reliability in the diagnosis of bone metastases of lung cancer, and RANKL-targeting agents could serve as a rational approach for the prevention of bone metastases $(60,61)$.

The therapeutic effect of RANK-targeting denosumab in the treatment of advanced breast cancer, prostate cancer, and multiple myeloma was demonstrated in a series of phase III studies (62-65). Recently, a randomized, open-label, phase III SPLENDOUR trial was designed to evaluate the treatment of denosumab in patients with advanced lung cancer. The addition of denosumab to chemotherapy in the intent-to-treat population and subgroups with or without bone metastases did not lead to improvement in OS (66). Of note, denosumab was welltolerated, without unexpected safety concerns. Clinical trials of denosumab that are currently recruiting patients are listed in Table 5. Moreover, some studies revealed the effect of serum RNA levels of RANK, RANKL, and OPG in the evaluation of zoledronate acid therapy in patients (61). Additionally, the use of thrombospontin was considered for the prevention of osteoporosis and bone metastases (67).

\section{OSTEOBLAST- AND BONE FORMATION- ASSOCIATED BIOMARKERS}

Lung cancer cells implanted in bone loci also affect the activity of osteoblasts in the microenvironment. Osteoblasts are activated by a large amount of growth factors and mediated by certain osteoclast-secreted proteins, which could to some extent predict the skeletal invasion of cancer cells (22).

\section{Total Serum Alkaline Phosphatase/Bone Specific Alkaline Phosphatase (TAP/BAP)}

TAP is widely distributed in the body with a series of isoenzymes. TAP lacks diagnostic specificity because of its sensitivity to several non-neoplastic diseases, such as liver cancer or cholecystitis. 68] Thus, few research studies focus on TAP. Instead, BAP is thought to be a reliable marker reflecting osteoblast activity and mineralization as one of the isoenzymes of TAP. Aruga et al. (68) and Ebert et al. (42) proved that the concentrations of TAP and BAP were significantly higher in patients with bone metastasis than those without $(\mathrm{p}<0.01)$. Lumachi et al. (69) proposed that there is no correlation between age and BAP $(\mathrm{R}=-0.10, \mathrm{p}=0.61)$ among patients with bone metastases. Bayrak et al. (28) obtained a BAP threshold value of $22.38 \mu \mathrm{g} / \mathrm{l}$ with sensitivity of $60.87 \%$ and specificity of $69.05 \%$. Similarly, Tang et al. (33) obtained cut-off values of 21.8 $\mu \mathrm{g} / \mathrm{l}$ with an AUC of 0.760 . Notably, there are two age-dependent physiological peaks of serum BAP at infancy and puberty. These peaks in levels are associated with altered longitudinal growth and may affect the reliability of results (70). These studies 
revealed that BAP plays an important role in predicting bone metastasis of lung cancer, while its clinical use require more limitation, such as age.

\section{Osteocalcin (OC)}

OC is the most abundant non-collagenic protein in the bone extracellular matrix. It is only produced by osteoblasts and odontoblasts under the control of vitamin D3 $(71,72)$. OC and fragments of the peptide are released during bone resorption, indicating its potential role as a marker of bone metastasis. Karapanagiotou et al. (43) and Terpos et al. (44) demonstrated that decreased OC serum levels were detected in NSCLC patients with bone metastases. In contrast, Bayrak et al. (28) argued that the levels of OC were not significantly different between the bone metastasis and no metastasis groups. Therefore, considering its limited accuracy and stability, OC may not be an ideal choice for predicting bone metastasis.

\section{Osteopontin (OPN)}

OPN is a sibling glycoprotein first identified in osteoblasts. It is defined as an extracellular matrix protein, which plays a vital role in the mineralization and absorption of bone matrix (72). In the other side, OPN regulates the migration and adhesion of tumor cells by binding to its receptor CD44. A study confirmed that OPN is overexpressed in NSCLC tumor tissues compared with their adjacent normal counterparts, and significantly correlated with TNM stages and lymph metastasis (73). Karapanagiotou et al. (43) and Terpos et al. (44) found increased serum levels of OPN in NSCLC patients with bone metastases. Moreover, Zhen et al. (74) performed a study of 105 patients and constructed a molecular model utilizing four serum biomarkers. As a potential therapeutic target, OPN with different genotypes was further investigated. Chen et al. (75) also compared the bone metastasis rate of three promoter OPN polymorphisms, namely the -OPN$66 \mathrm{~T} / \mathrm{G},-156 \mathrm{G} / \mathrm{GG}$, and $-443 \mathrm{C} / \mathrm{T}$ variants, from the DNA of blood lymphocytes. They declared that patients with the -443 (CC) variant had a significantly higher incidence of bone metastasis compared with the other genotypes.

CD44 is a cell-surface receptor for OPN and mediates epithelial-mesenchymal transition; hence, it is related to tumor migration (76). Liu et al. (77) genotyped the CD44 gene in DNA extracted from blood lymphocytes of patients with NSCLC and found that the rs187115 (AG+GG) genotype was a significant predictor of bone metastasis and poor survival. It is widely accepted that the detection of single nucleotide polymorphisms in CD44 and other genes would be helpful in assessing the invasion ability of tumors (78).

\section{Amino-Terminal Extension Propeptide of Type I Procollagen/Carboxy-Terminal Extension Propeptide of Type I Procollagen (PINP/PICP)}

PICP and PINP are produced by the extracellular cleavage of a molecule of type I procollagen at the moment of its incorporation into the bone matrix (71). The concentrations of PICP and PINP, reflecting the rate of synthesis of type I collagen, are altered by the liver where they are degraded. Kobayashi et al. (79) demonstrated that the serum levels of PINP were significantly correlated with the clinical stage, extent of bone metastasis, survival time, levels of D-dimer, and tumor size in lung cancer. In 2004, Elbert et al. (42) demonstrated that the concentration of PINP was significantly higher in patients with bone metastasis than those without $(\mathrm{p}<0.01)$, with sensitivity and specificity of $18.4 \%$ and $97.5 \%$, respectively. Other researchers, including Lüftner et al. (80), assessed the predictive effect of the serum levels of PINP on the osseous spread of breast and prostate cancer, while studies on lung cancer are limited and require more attention.

\section{Bone Sialoprotein (BSP)}

BSP, a sulfated phosphoprotein enriched in bone and other mineralized tissue, is critical in elucidating the formation of bone metastases (81). In 1997, Bellahcene et al. (82) found that BSP was not detected in normal lung tissue, except the cartilage in bronchi. On the contrary, most of the adenocarcinomas and all squamous carcinomas among the 86 tested lung tissues had detectable levels of BSP. Moreover, Zhang et al. (83) further declaimed that BSP expression in patients with tumor-resected NSCLC is significantly correlated with bone metastasis and can be utilized to identify high-risk patients after primary tumor resection. Similarly, He et al. (84) revealed that the serum levels of BSP could be used to evaluate bone metastasis, with a cut-off value of $33.56 \mathrm{ng} / \mathrm{ml}$, sensitivity of 77.8 , and specificity of $81.1 \%$. Collectively, these findings indicated that BSP is a stable component of a bone metastasis predictive model, like in the study conducted by Zhou et al. (74).

\section{BONE METASTASIS-ASSOCIATED SIGNALING MARKERS}

Osteoclast and osteoblast functions are thought to be essential in bone metastasis for different types of lung cancer, and varying degrees of osteolytic and osteoblastic activities have been observed. As expected, more potential markers are involved in the progression of osteolytic and osteoblastic metastasis, by mediating downstream proteins or the signaling axis. These markers should be taken into consideration for the early diagnosis of lung cancer bone metastasis, although the mechanisms involved in this process remain unknown (81).

\section{Epidermal Growth Factor Receptor/ Kirsten Rat Sarcoma/Anaplastic Lymphoma Kinase (EGFR/KRAS/ALK) Axis}

Lung cancer is often driven by molecular alterations, such as EGFR and KRAS mutations, and ALK rearrangements expressed in tumor tissues of patients with NSCLC. Fujimoto et al. (85) demonstrated that patients with EGFR mutations $(\mathrm{N}=98)$ had significantly more metastatic lesions in the brain and bone than those in the wild-type group. In addition, EGFR mutations were significantly more frequent in patients with multiple lung metastases than a single lung metastasis (24/40 vs. 12/42, 
respectively; $p=0.004$ ). Kuijper et al. (86) found that EGFR+ tumors were linked to more frequent metastases to the bone (31.5\% vs. $53.8 \%$, respectively) and pleura $(24.1 \%$ vs. $37.5 \%$, respectively) compared with triple-negative tumors. Of note, Hendriks et al. (87) and Dormieux et al. (88) showed that the incidences of brain and bone metastases were not different between EGFR+, KRAS+, and wild-type patients. Nevertheless, Zang et al. (13) and Amelot et al. (89) revealed that OS was associated with the EGFR status in patients with NSCLC spinal metastasis.

EGFR mutations may also be a useful prognostic factor for the response to EGFR tyrosine kinase inhibitors (TKIs) (90). The majority of these mutations are located in the catalytic kinase domain of EGFR. Typical mutations include a deletion within exon 19 (E19del) or a leucine-to-arginine point mutation at codon 858 (L858R) within exon 21 (91). The detection of E19del and L858R by immunohistochemistry predicts the effectiveness of first-generation EGFR TKIs (e.g., gefitinib and erlotinib) and second-generation TKIs (e.g., afatinib) $(92,93)$. Other studies identified T790M mutations in EGFR exon 20 as predictors for the development of resistance to first-generation EGFR TKIs (94-96). According to the phase III AURA-3 trial, treatment of patients with T790M mutations using osimertinib resulted in a better clinical outcome compared with chemotherapy, with an objective response rate of $71 \%$ versus $31 \%$, respectively, and median progression-free survival (PFS) of 10.1 versus 4.4 months, respectively (97). In the phase III FLAURA study involving 556 patients with untreated EGFR-mutated NSCLC, osimertinib significantly enhanced the objective response rate, median PFS, and median OS compared with gefitinib or erlotinib $(98,99)$. Importantly, $49 \%$ of patients lost the T790M mutation during treatment with osimertinib, which predicted their resistance to osimertinib and worse outcome. This mutation is usually associated with the emergence of competing resistance mechanisms, such as KRAS mutations, c-MET amplification, small-cell transformation, and gene fusion (100, 101). Furthermore, mutations (e.g., L792, L718, G719, and exon 20 insertions) may predict exceedingly poor responses to osimertinib and standard TKIs; however, their exact prognostic and predictive roles are not fully clarified (102-104). Some potential TKIs targeting these mutations, including roziotinib and TAK-788, remain under clinical investigation (Table 1). It is assumed that the EGFR mutations of primary lung cancer could forecast the prognosis of patients with bone metastasis and tumor response to TKI therapy.

The ALK rearrangement is present in approximately $8 \%$ of NSCLC patients with oncogenic drivers (109). Dormieux et al. (88) demonstrated that the group with ALK fusions developed

TABLE 1 | Studies on bone resorption markers.

\begin{tabular}{|c|c|c|c|c|}
\hline Marker & Reference & $\begin{array}{l}\text { Sample } \\
\text { location }\end{array}$ & $\begin{array}{l}\text { Sample } \\
\text { size (N) }\end{array}$ & Finding \\
\hline $\begin{array}{l}\text { NTx } \\
\text { and }\end{array}$ & $\begin{array}{l}\text { Jablonka et al. } \\
\text { (105) }\end{array}$ & Serum & 181 & $\begin{array}{l}\text { Serum NTx levels were significantly higher in patients with solid tumor and bone metastasis (BM) than in those } \\
\text { without BM and in normal controls. }\end{array}$ \\
\hline \multirow[t]{4}{*}{ CTx } & Kaira et al. (106) & Urine & 30 & $\begin{array}{l}\text { In } 30 \text { patients, the median NTx levels at } 1 \text { month after one cycle of chemotherapy were significantly lower than } \\
\text { those at baseline }(p=0.0016) \text {. }\end{array}$ \\
\hline & $\begin{array}{l}\text { Bayrak et al. } \\
(107)\end{array}$ & Serum & 65 & $\begin{array}{l}\text { At the threshold value of } 25.69 \text { nmol BCE, the sensitivity of BM diagnosis of NTx was } 90.24 \% \text { and the specificity } \\
\text { was } 43.4 \% \text {. }\end{array}$ \\
\hline & $\begin{array}{l}\text { Huang et al. } \\
(108)\end{array}$ & Serum & 1,720 & NTx was significantly lower among patients with BM than those without BM. \\
\hline & $\begin{array}{l}\text { Zhang et al. } \\
(106)\end{array}$ & Serum & 1,279 & $\begin{array}{l}\text { There was a significant relationship between serum NTx concentration and BM from solid tumors in the Chinese } \\
\text { population. }\end{array}$ \\
\hline \multirow[t]{4}{*}{ I-CTP } & $\begin{array}{l}\text { Yokoyama et al. } \\
\text { (34) }\end{array}$ & Serum & 87 & $\begin{array}{l}\text { I-CTP was significantly higher in patients with BM than those without BM. The most efficient cut-off value for I- } \\
\text { CTP computed in this study was } 6.4 \mathrm{ng} / \mathrm{ml} \text {. }\end{array}$ \\
\hline & $\begin{array}{l}\text { Charpko et al. } \\
\text { (36) }\end{array}$ & Serum & 60 & $\begin{array}{l}\text { The levels of bone pathological degradation (I-CTP) and bone formation reflected the extent of metastatic } \\
\text { disease in bone measured by }{ }^{99 \mathrm{~m}} \mathrm{~T} \text {-MDP scans. }\end{array}$ \\
\hline & Kong et al. (37) & Serum & 126 & $\begin{array}{l}\text { The levels of both } \beta \text {-CTX and I-CTP were significantly higher in lung cancer patients with BM (both } p<0.001) \text { and } \\
\text { ICTP had a better sensitivity and accuracy than } \beta \text {-CTX. }\end{array}$ \\
\hline & $\begin{array}{l}\text { Tanaka et al. } \\
\text { (35) }\end{array}$ & Serum & 143 & $\begin{array}{l}\text { The rate of distant metastasis was significantly higher in patients with elevated preoperative serum I-CTP levels } \\
\text { than those with normal preoperative I-CTP levels }(\leq 4.5 \mathrm{ng} / \mathrm{ml})(\mathrm{p}<0.0001)\end{array}$ \\
\hline \multirow[t]{4}{*}{$\begin{array}{l}\text { TRACP- } \\
5 b\end{array}$} & Ebert et al. (41) & Serum/urine & 146 & $\begin{array}{l}\text { There was no significant difference in TRACP-5b activity between lung cancer patients with BM versus those } \\
\text { without. Power as a diagnostic marker is low. Does not correlate with the extent of BM. }\end{array}$ \\
\hline & $\begin{array}{l}\text { Terpos et al. } \\
(43)\end{array}$ & Serum & 79 & Elevated TRACP-5b at diagnosis increased the risk of disease progression. \\
\hline & $\begin{array}{l}\text { Karapanagiotou } \\
\text { et al. (42) }\end{array}$ & Serum & 68 & There was no significant difference between patients with lung cancer with or without BM and the control group. \\
\hline & Tang et al. (33) & Serum & 265 & The TRACP-5b value was higher in patients with BM than those without BM $(p<0.0001)$ \\
\hline \multirow[t]{2}{*}{$\begin{array}{l}\text { PYD, D- } \\
\text { PYD }\end{array}$} & Ebert et al. (41) & Serum & 150 & $\begin{array}{l}\text { PYD and D-PYD were higher }(\mathrm{p}<0.01-0.05) \text { in patients with } \mathrm{BM} \text {. The sensitivity (specificity) values were } 91.8 \% \\
(24.1 \%) \text { and } 83.7 \%(34.5 \%) \text { for PYD and D-PYD, respectively. }\end{array}$ \\
\hline & Dane et al. (46) & Urine & 60 & $\begin{array}{l}\text { The high urinary levels of D-PYD may be an early sign of metastases in patients without BM assessed by } \\
\text { scintigraphic techniques. }\end{array}$ \\
\hline PTHrP & Katseli et al. (49) & $\begin{array}{l}\text { Circulating } \\
\text { tumor cells }\end{array}$ & 125 & PTHrP mRNA detection correlated positively with lung cancer stage, presence of BM, and squamous cell carcinoma. \\
\hline
\end{tabular}

AUC, area under the curve; BCE, bone collagen equivalents; $\beta$-CTX, beta-type collagen carboxy-terminal peptide; CTX, C-terminal telopeptide; $D$-PYD, deoxypyridinoline; I-CTP, C-terminal telopeptide of type I collagen; NTX, N-terminal telopeptide; TRACP-5b, tartrate-resistant acid phosphatase isoform-5b; PTHrP, parathyroid hormone related peptide; PYD, pyridinoline. 
more brain and lung metastases compared with the negative group, with rates of $42 \%$ versus $29 \%$ and $37 \%$ versus $24 \%$, respectively. Despite the absence of a direct correlation between ALK fusions and bone metastasis, the detection of these rearrangements contributes to the classification of target therapies for lung cancer patients with bone metastasis. The phase III PROFILE 1014 trial compared crizotinib with chemotherapy and demonstrated better objective response rate and PFS in ALK-positive patients (110). Moreover, the secondgeneration ALK-TKIs ceritinib, alectinib, and brigatinib, and the third-generation ALK TKI lorlatinib, showed an enhanced effect on the treatment of ALK-rearranged NSCLC compared with crizotinib. A variety of secondary ALK point mutations (e.g., L1196M, G1202R, S1206Y, and 1151Tins) were detected in patients with progressed disease, some of which predicted resistance to crizotinib (111-113). Recent clinical trials are presented in Table 2.

KRAS mutations are among the most commonly found mutations in NSCLC (20-30\% of cases) (114-116). Its mutations mainly occur in codons 12,13 , and 61 , which are thought to be diagnostic factors of bone metastasis of lung cancer. Renaud et al. (117) claimed that patients with KRAS G12C rearrangement developed significantly more bone metastases compared with those in the control group of the cohort $(59 \%$ vs. $16 \%$, respectively; $\mathrm{p}<0.0001)$ after thoracic surgery for NSCLC. Currently, there are two investigational KRAS G12C inhibitors, namely AMG 510 and MRTX849 (Table 3), which have shown $40-50 \%$ response rate in some pre-treated patients $(106,123,124)$. Further investigation of other specific therapies may reveal that KRAS mutations could also be useful for the classification of KRAS-targeted therapy.

Most of the EGFR mutations are measured by tumor tissue immunohistochemistry through wounded puncture or surgery. Yao et al. (125) found a correlation between EGFR mutations and ${ }^{18} \mathrm{~F}$-fluorodeoxyglucose positron emission tomographycomputed tomography imaging, and attempted to use this non-invasive inspection as an independent predictor. It was also verified that circulating tumor DNA (ctDNA) in the plasma can be used to detect EGFR mutations in patients with NSCLC, providing information similar to that obtained from biopsies (126). Therefore, the predictive effect of EGFR mutations, ALK rearrangements, and KRAS mutations are with great clinical potential.

\section{C-Mesenchymal-Epithelial Transition Factor/Hepatocyte Growth Factor (c-MET/ HGF) Signaling Axis}

c-MET is a receptor tyrosine kinase, and HGF is its sole ligand. The dysregulation of c-MET and HGF in tumor progression and invasion interplay with other signaling pathways, such as the EGFR pathway $(92,118,119)$. The prevalence of MET amplification and MET exon 14 skipping mutation (METex14) is approximately $5 \%$ and $2 \%$, respectively.

In 2009, Navab et al. (120) performed a study involving the overexpression of c-MET and HGF, resulting in enhanced metastases to distant organs (e.g., bone, brain, and kidneys). Following a series of studies, c-MET was thought to be a biomarker for NSCLC, which could be measured by immunohistochemistry and qualified with the $\mathrm{H}$-score ranging from 0 to 300. Tsakonas et al. (119) demonstrated that a c-MET $\mathrm{H}$ score $\geq 20$ is a positive prognostic biomarker for OS in patients with early-stage NSCLC, and could also be used to predict the effect of platinum-based adjuvant chemotherapy. Notably, Grano et al. (127) conducted the first important study describing the expression and roles of c-MET and HGF in osteoblasts and osteoclasts. Moreover, Whang et al. (128) demonstrated that the c-MET and HGF signaling axis played an essential role in the metastatic bone microenvironments. Moreover, the expression

TABLE 2 | Studies on bone formation markers.

\begin{tabular}{|c|c|c|c|c|}
\hline Marker & Reference & $\begin{array}{l}\text { Sample } \\
\text { location }\end{array}$ & $\begin{array}{l}\text { Sample } \\
\text { size }(\mathrm{N})\end{array}$ & Finding \\
\hline \multirow[t]{3}{*}{ BAP/TAP } & $\begin{array}{l}\text { Lumachi et al. } \\
\text { (57) }\end{array}$ & Serum & 35 & Using a cut-off value of $50 \mathrm{U} / \mathrm{l}$ for BAP, the sensitivity and specificity were $37.5 \%$ and $84.2 \%$, respectively. \\
\hline & $\begin{array}{l}\text { Bayrak et al. } \\
\text { (28) }\end{array}$ & Serum & 65 & $\begin{array}{l}\text { Serum levels of total ALP and BAP were significantly higher in the group with bone metastasis }(p<0.05) \text {. } \\
\text { According to the ROC curve analysis, at the threshold value of } 22.38 \mu \mathrm{g} / \mathrm{l} \text {, the sensitivity and specificity of } \\
\text { BAP were } 60.87 \% \text { and } 69.05 \% \text {, respectively. }\end{array}$ \\
\hline & Tang et al. (33) & Serum & 143 & $\begin{array}{l}\text { The area under the ROC curve (AUC) of BAP was } 0.760 \text { ( } \mathrm{p}<0.0001) \text {. The cut-off value for BAP was } 21.8 \\
\mu \mathrm{g} / \mathrm{l} \text {. }\end{array}$ \\
\hline \multirow[t]{3}{*}{$\begin{array}{l}\text { Osteocalcin } \\
\text { (OC) }\end{array}$} & $\begin{array}{l}\text { Karapanagiotou } \\
\text { et al. (42) }\end{array}$ & Serum & 68 & Decreased OC and increased OPN serum levels were detected in NSCLC patients with bone metastasis. \\
\hline & $\begin{array}{l}\text { Terpos et al. } \\
\text { (43) }\end{array}$ & Serum & 79 & $\begin{array}{l}\text { OC was significantly decreased in the group of patients who developed bone metastasis at some point } \\
\text { during the course of their disease. Patients with bone metastasis showed an increase in OPN. }\end{array}$ \\
\hline & $\begin{array}{l}\text { Bayrak et al. } \\
(28)\end{array}$ & Serum & 65 & OC was not significantly different between the group with and without bone metastasis. \\
\hline $\begin{array}{l}\text { Osteopontin } \\
\text { (OPN) }\end{array}$ & Chen et al. (63) & $\begin{array}{l}\text { Blood } \\
\text { lymphocytes }\end{array}$ & 360 & $\begin{array}{l}\text { Patients with the OPN-443 (CC) variant had a significantly higher incidence of bone metastasis compared } \\
\text { with other genotypes. }\end{array}$ \\
\hline \multirow[t]{2}{*}{ PINP/PICP } & $\begin{array}{l}\text { Kobayashi et al. } \\
\text { (67) }\end{array}$ & Serum & 59 & $\begin{array}{l}\text { PINP was significantly correlated with clinical stage, extent of bone metastasis, survival time, D-dimer, and } \\
\text { tumor size. }\end{array}$ \\
\hline & Ebert et al. (41) & Serum & 150 & $\begin{array}{l}\text { The concentration of PINP was significantly higher in patients with bone metastasis }(\mathrm{p}<0.01) \text {. The sensitivity } \\
\text { (specificity) values for PINP and PICP were } 18.4 \%(97.5 \%) \text { and } 2.1 \%(95.2 \%) \text {, respectively. }\end{array}$ \\
\hline
\end{tabular}

ALP, alkaline phosphatase; BAP, bone specific alkaline phosphatase; NSCLC, non-small-cell lung cancer; PICP, carboxy-terminal extension propeptide of type I procollagen; PINP, aminoterminal extension propeptide of type I procollagen; ROC, receiver operating characteristic; TAP, total serum alkaline phosphatase. 
TABLE 3 | Current studies on signaling markers.

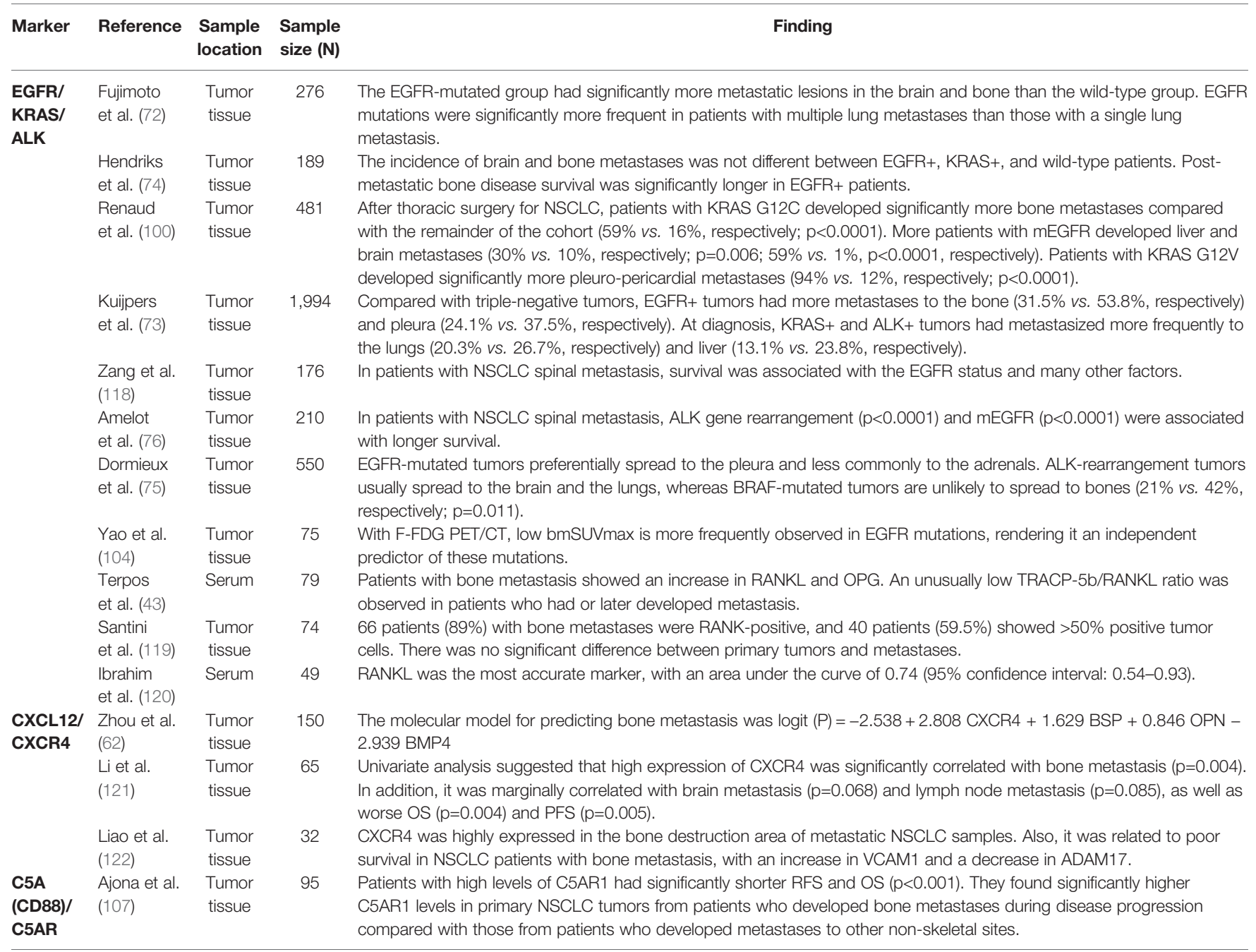

ADAM17, ADAM metallopeptidase domain 17; ALK, anaplastic lymphoma kinase; bmSUVmax, maximum standardized uptake value in bone metastasis; C5A, complement component 5a; C5AR, complement component 5a receptor; CXCL12, C-X-C motif chemokine ligand 12; CXCR4, C-X-C motif chemokine receptor 4; EGFR, epidermal growth factor receptor; F-FDG $P E T / C T$, fluorodeoxyglucose positron emission tomography/computed tomography; KRAS, Kirsten rat sarcoma; mEGFR, EGFR mutation; NSCLC, non-small-cell lung cancer; OPG, osteoprotegerin; OS, overall survival; PFS, progression-free survival; RFS, recurrence-free survival; TRACP-5b, tartrate-resistant acid phosphatase isoform-5b; RANK, receptor activator of nuclear factor $\mathrm{kB}$; RANKL, receptor activator of nuclear factor $\mathrm{KB}$ ligand; VCAM1, vascular cell adhesion molecule 1.

of c-MET and HGF was correlated with the progression of bone metastasis. The expression of this axis was also viewed as a prognostic biomarker, representing the clinical response of patients with advanced lung cancer and prostate cancer to cMET- and vascular endothelial growth factor receptor 2 (VEGFR2)-targeted therapy $(92,118,129)$.

Currently, there is no approved therapy targeting c-MET, while several c-MET inhibitors (e.g., crizotinib, cabozantinib, tepotinib, telisotuzumab, etc.) are being investigated in clinical trials. Table 4 presents the details of these clinical trials. According to a retrospective study, MET inhibitors are associated with prolonged OS of patients with metastatic METex14 NSCLC $(130,131)$. Secondary c-MET amplification is the most frequent cause of EGFR-TKIs tolerance. Following the administration of osimertinib as first-line therapy, MET amplification (encountered in $15 \%$ of patients) was the most common mechanism of intrinsic resistance (99). Moreover, $>50 \%$ of the EGFR T790M-positive patients retained the c-MET amplification, and c-MET mutations are likely to be associated with EGFR C797S, CDK6, and BRAF amplifications $(131,132)$. Despite the absence of specific research regarding the predictive effects of c-MET and HGF, their predictive roles in the prognosis of patients with bone metastases are worthy of further investigation.

\section{C-X-C Motif Chemokine Ligand 12/C-X-C Motif Chemokine Receptor 4 (CXCL12) CXCR4) Axis}

CXCR4, a chemokine receptor, and its sole agonist CXCL12 [stromal cell-derived factor 1 (121)] play an important role in lung cancer. Their scavenger receptor, atypical chemokine receptor 3 (ACKR3; CXCR7), also participates in tumor progression.

Higher levels of CXCR4 are correlated with poor prognosis and a high risk of skeletal-related events in patients with NSCLC. 
TABLE 4 | Current studies on other markers.

\begin{tabular}{|c|c|c|c|c|}
\hline Marker & Reference & $\begin{array}{l}\text { Sample } \\
\text { location }\end{array}$ & $\begin{array}{l}\text { Sample } \\
\text { size (N) }\end{array}$ & Finding \\
\hline CASR & $\begin{array}{l}\text { Liu et al. } \\
(174)\end{array}$ & $\begin{array}{l}\text { Tumor } \\
\text { tissue }\end{array}$ & 120 & $\begin{array}{l}\text { CASR expression in lung cancer tissues was significantly higher than that measured in adjacent and normal lung } \\
\text { tissues. The expression of CASR in lung cancer tissues with BM was higher than that observed in non-metastatic lung } \\
\text { cancer tissues. }\end{array}$ \\
\hline \multirow[t]{3}{*}{ BSP } & $\begin{array}{l}\text { Bellahcene } \\
\text { et al. (33) }\end{array}$ & $\begin{array}{l}\text { Primary } \\
\text { lung tumor } \\
\text { tissue }\end{array}$ & 86 & $\begin{array}{l}\text { BSP was not specifically detected in normal lung tissue with the exception of cartilage associated with bronchi. Most } \\
\text { adenocarcinoma }(74 \%) \text { and all squamous carcinoma of the lung samples examined exhibited detectable levels of BSP. }\end{array}$ \\
\hline & $\begin{array}{l}\text { Zhang } \\
\text { et al. (70) }\end{array}$ & $\begin{array}{l}\text { Primary } \\
\text { lung tumor } \\
\text { tissue }\end{array}$ & 180 & $\begin{array}{l}\text { BSP protein expression in the primary resected NSCLC was strongly associated with BM and could be used to } \\
\text { identify high-risk patients after primary tumor resection. }\end{array}$ \\
\hline & $\begin{array}{l}\text { He et al. } \\
(71)\end{array}$ & Serum & 146 & $\begin{array}{l}\text { The mean serum BSP levels in individuals with BM were significantly higher than those recorded in non-BM NSCLC } \\
\text { and controls }(p<0.001) \text {. The cut-off value was } 33.56 \mathrm{ng} / \mathrm{ml} \text {, and sensitivity and specificity values were } 77.8 \% \text { and } \\
81.1 \% \text {, respectively. }\end{array}$ \\
\hline \multirow[t]{4}{*}{ BMP2 } & $\begin{array}{l}\text { Bieniasz } \\
\text { et al. (168) }\end{array}$ & $\begin{array}{l}\text { Tumor } \\
\text { tissue }\end{array}$ & & $\begin{array}{l}\text { The expression levels of VEGF, BMP2, and BMP4 mRNA were significantly higher (7.1-fold, 25.6-fold, and 2.3-fold, } \\
\text { respectively) in lung cancer samples than those in adjacent normal lung tissues. }\end{array}$ \\
\hline & $\begin{array}{l}\text { Choi et al. } \\
(169)\end{array}$ & Serum & 150 & $\begin{array}{l}\text { The NSCLC group demonstrated significantly higher levels of serum BMP2 than the control group. The median serum } \\
\text { levels of BMP2 in the advanced stage group (stage IIIb or IV) were significantly elevated compared with those of the } \\
\text { localized stage group (stages I, II, and IIla). }\end{array}$ \\
\hline & $\begin{array}{l}\text { Fei et al. } \\
(170)\end{array}$ & Serum & 84 & $\begin{array}{l}\text { Serum BMP2 levels were significantly decreased in patients who achieved objective response after two cycles of } \\
\text { chemotherapy. }\end{array}$ \\
\hline & $\begin{array}{l}\text { Huang } \\
\text { et al. (171) }\end{array}$ & $\begin{array}{l}\text { Tumor } \\
\text { tissue }\end{array}$ & $\begin{array}{l}\text { in vivo } \\
\text { study }\end{array}$ & Activation of BMP2 signaling can enhance BM of Lewis lung carcinoma. \\
\hline $\begin{array}{l}\text { CYFRA } \\
\text { and CEA }\end{array}$ & $\begin{array}{l}\text { Numata } \\
\text { et al. (182) }\end{array}$ & $\begin{array}{l}\text { Serum/ } \\
\text { tumor } \\
\text { tissue }\end{array}$ & 131 & $\begin{array}{l}\text { Elevated serum CEA and CYFRA levels appear to provide useful clinical information on the presence of BM and liver } \\
\text { metastasis, as well as multiple-organ metastases, although they were not a powerful indicator of prognosis. }\end{array}$ \\
\hline $\begin{array}{l}\text { Tissue } \\
\text { factor }\end{array}$ & $\begin{array}{l}\text { Xia et al. } \\
(186)\end{array}$ & Serum & 100 & $\begin{array}{l}\text { Patients with high tissue factor expression levels tended to have worse overall survival performance, and } \\
\text { downregulation of tissue factor inhibited the invasion and metastasis of NSCLC cells in vitro and in vivo. }\end{array}$ \\
\hline $\begin{array}{l}\text { Cell-free } \\
\text { DNA }\end{array}$ & $\begin{array}{l}\text { Pecuchet } \\
\text { et al. (192) }\end{array}$ & Serum & 124 & The presence of circulating tumor DNA at baseline was an independent marker of poor prognosis. \\
\hline \multirow[t]{2}{*}{ (cfDNA) } & $\begin{array}{l}\text { Ettinger } \\
\text { et al. (83) }\end{array}$ & Serum & 282 & DNA median turnaround time was significantly shorter than that of tissue ( 9 vs. 15 days, respectively; $p<0.0001$ ) \\
\hline & $\begin{array}{l}\text { Ye et al. } \\
(193)\end{array}$ & $\begin{array}{l}\text { Tumor } \\
\text { tissue }\end{array}$ & 186 & Patients with BM had higher concentrations of cfDNA and worse survival outcome. \\
\hline
\end{tabular}

BM, bone metastasis; BMP2, bone morphogenetic protein 2; BSP, bone sialoprotein; CASR, calcium sensing receptor; CEA, carcinoembryonic antigen; CYFRA, cytokeratin 19 fragment; NSCLC, non-small-cell lung cancer; VEGF, vascular endothelial growth factor.

Regarding patients with lung cancer, a univariate analysis conducted by Li et al. (133) suggested that high expression of CXCR4 was significantly associated with bone metastasis, as well as worse OS and PFS, and was marginally correlated with brain and lymph node metastasis. Zhou et al. (74) constructed a predictive model for bone metastasis, in which CXCR4 demonstrated an important role.

Several studies have shown that the CXCR4/CXCL12 interaction may foster local tumor growth and metastatic potential by maintaining an immune-quiescent microenvironment, which could be blocked by CXCR4 antagonism (134-138). It was also reported that the majority of NSCLC tumors expressed CXCL12 in the cytomembranous compartment, and strong staining for CXCL12 was associated with a higher incidence of disease recurrence (139). Other studies suggested that high CXCL12 expression in lymph nodes promoted the metastasis of CXCR4expressing cells, benefiting from autocrine CXCL12/CXCR4 (121). Some meta-analyses have evaluated the whole effects of CXCL12/ CXCR4 expression on NSCLC. The results supported that CXCR4 expression is correlated with lymph node metastasis, distant metastasis, tumor stage, and OS (140-142). Collectively, these studies proposed that CXCR4 is a predictive biomarker for bone metastasis and its prognosis.
The CXCL12/CXCR4 axis greatly contributes to certain tumormediated metastases and is thought to be a potential target of CXCR4 antagonists $(143,144)$. CXCR4 antagonists can be categorized into four major groups: nonpeptide CXCR4 antagonists (e.g., AMD3100); small peptide CXCR4 antagonists (e.g., BL-8040); antibodies to CXCR4 (e.g., LY 2624587 and ulocuplumab); and modified agonist CXCL12 antagonists (e.g., NOX-12A) (134, 145, 146). A series of clinical trials utilizing CXCR4 inhibitors were conducted in the field of hematological malignancies, while only a few clinical trials evaluated their safety and effectiveness in solid malignancies (147). Notably, small peptide LY2510924 exhibited limited clinical efficacy in the treatment of advanced SCLC (148). Therefore, it is essential to produce adequate evidence on the therapeutic role of CXCL12/CXCR4 in lung cancer and bone metastasis.

Moreover, the CXCL12/CXCR4 axis participates in other mechanisms of cancer progression. Recent findings indicated that CXCR4 expression on tumor cells plays a positive role in key downstream pathways, including PI3K/AKT/mechanistic target of rapamycin kinase (PI3K/AKT/MTOR) and extracellular signal-regulated kinase $1 / 2(\mathrm{ERK} 1 / 2)$, which promote tumor proliferation and migration (149). Vascular cell adhesion molecule 1 (VCAM1) was also shown to be an activator of 
CXCR4, with ADAM metallopeptidase domain 17 (ADAM17) as a downstream mediator (122). Zuo et al. (150) demonstrated that overexpression of CXCR4 enhanced cell motility and invasion via EGFR and matrix metallopeptidase 9 (MMP9), owing to the positive correlation among them. Furthermore, CXCR4 regulates the migration of lung cells through activation of Rac family small GTPase 1 (RAC1) and matrix metalloproteinases (MMP2 and MMP14), and through the action of inhibitor of kappa kinase (IKK), ERK, NF-KB, and integrins (151, 152). Research has demonstrated the potential of CXCR4 antagonists to enhance the efficacy of immune checkpoint inhibitors in some types of solid tumor by inducing an immune suppressive tumor microenvironment (153-155). In summary, the predictive role of CXCL12/CXCR4 axis is reliable; however, the exact mechanism and therapeutic utilization of this axis warrant further verification.

\section{Complement Component 5a/Complement Component 5a Receptor (C5A/C5AR) Axis}

The complement system represents a central component of innate immunity mediated by the proteolytic cleavage of C3 and C5. Cleaved products $\mathrm{C} 3 \mathrm{~b}$ and $\mathrm{C} 5 \mathrm{~b}$ participate in a variety of adaptive immune processes via membrane attack complex-dependent killing. Ajona et al. (107) demonstrated that blockage of the C5A/ C5AR axis led to a substantial improvement in the efficacy of antiprogrammed cell death 1 (anti-PD-1) immune responses in patients with lung cancer. Since then, C5AR-targeted therapy has been considered an advanced complementary therapy for clinical use. Furthermore, the C5A/C5AR axis is thought to be a reliable predictor of lung cancer bone metastasis. This is because patients who developed bone metastases had significantly higher C5AR1 levels in the primary tumor versus those with metastases to other non-skeletal sites during disease progression (108). To further investigate the mechanism of the C5A/C5AR axis, Vadrevu et al. (156) performed in vitro experiments and hypothesized that C5AR facilitates metastasis by suppressing effector CD8+ and CD4+ Tcells responses in the lungs. Recruitment of immature myeloid cells, generation of $\mathrm{T}$ regulatory cells, and secretion of factors, such as CXCL16, transforming growth factor beta (TGF- $\beta$ ), and interleukin 10 (IL10), may be involved in the mechanisms of this suppressor $(108,157)$.

\section{Notch Signaling Pathway}

NOTCH3, a transmembrane receptor and a member of the Notch signaling pathway, plays an essential role in the development of lung cancer (158). It is overexpressed in approximately $40 \%$ of NSCLCs and has been associated with poorer disease-free survival and OS, higher TNM stage, poorer response to chemotherapy, and an increased rate of lymph node metastasis. Therefore, it is an ideal biomarker for the prediction of prognosis of NSCLC $(105,159-161)$. In NSCLC and SCLC, NOTCH3 signaling acts as a tumor-promoting and -suppressing pathway, respectively (162). The functional differences, which depend on the type of tumor, are worthy of exploration. Li et al. (163) found that upregulation of Wnt family member 3A (WNT3A) enhanced the expression of NOTCH3 and its downstream genes, hes family bHLH transcription factor 1
(HES1) and hes related family bHLH transcription factor with YRPW motif like (HEYL), and promoted metastasis of NSCLC. Liu et al. (164) demonstrated that NOTCH3 increased the invasion ability of NSCLC by upregulating zinc finger E-box binding homeobox 1 (ZEB1), which contributed to TGF- $\beta$ induced transformation and bone metastasis in NSCLC. High levels of NOTCH3 are also associated with chemoresistance and resistance to radiotherapy, and inhibition of Notch enhances the sensitivity to EGFR kinase inhibitor $(159,165)$. Notch signaling inhibitors, including MRK-003, represent new approaches for the targeted therapy for lung cancer. These inhibitors, to some extent, contribute to the diverse treatment options for bone metastasis (161). In summary, mRNA expression in tissue or immunohistochemistry staining of $\mathrm{NOTCH} 3$ from primary tumor tissue are likely to be stable predictive methods for prognosis and response to chemotherapy in patients with advanced NSCLC.

\section{CXCL16/CXCR6 AXis}

CXCL16 is one of the most extensively studied transmembrane chemokines. It is lowly and highly expressed in lung tissues and specimens of bone metastasis, respectively (166). CXCR6 functions as the receptor of CXCL16, and the CXCL16/CXCR6 signaling system is involved in the progression of tumor growth. $\mathrm{Ha}$ et al. (166) demonstrated that high CXCL16/CXCR6 expression in prostate tumor tissue may be related to aggressive cancer behavior, as well as high CXCL16 expression in bone metastasis. Similarly, Na et al. (167) revealed that high mRNA expression levels and immunohistochemistry staining of CXCR6 and CXCL16 in Ewing sarcoma family tumors was associated with tumor progression and lung metastasis. Ajona et al. (108) found that CXCL16 participated in the blockage of the complement $\mathrm{C} 5 \mathrm{~A} / \mathrm{C} 5 \mathrm{AR}$ axis in lung cancer bone metastasis, suggesting that CXCL16 is also a potential biomarker for the prediction of lung cancer progression and bone metastasis.

\section{OTHER POTENTIAL BIOMARKERS}

The bone formation and resorption markers have been used clinically for several years, based on their direct correlation with the progression of bone metastasis and clear mechanism. However, the efficacy and mechanism of some potential biomarkers remain unknown. Numerous studies have suggested their usefulness in the early prediction of bone metastasis and their clinical therapeutic or prognostic effect.

\section{Bone Morphogenic Protein 2 (BMP2)}

BMP2 promotes the migration and invasion of NSCLC cells. Firstly, BMP2 expression is higher in tumor tissues than in adjacent normal lung tissues (168). Subsequently, Choi et al. (169) demonstrated significantly higher levels of serum BMP2 in patients with NSCLC versus the control group. In addition, the levels of BMP2 in the advanced stage group were significantly elevated compared with those measured in the localized stage group. Moreover, serum BMP2 has been strongly associated with the objective response to 
chemotherapy (170). Recently, Huang et al. (171) performed a series of in vivo experiments to certify that activation of BMP2 signaling can enhance bone metastasis of Lewis lung cancer through both osteolytic and osteoblastic mechanisms. Thus far, no retrospective research has directly analyzed the role of BMP2 in lung cancer bone metastasis. Nevertheless, it may be a useful noninvasive biomarker capable of prognostic utility.

\section{Calcium Sensing Receptor (CASR)}

CASR is a widely expressed $\mathrm{G}$ protein-coupled receptor, which is critical for maintaining metabolic balance between bone and calcium content (172). Its expression is low or absent in normal lung tissue, whereas it is significantly higher in lung cancer tissue (173). Moreover, Lian et al. (174) demonstrated that the expression of CASR in 120 cancer tissues with bone metastasis was significantly higher than that recorded in non-metastatic lung cancer tissues. Another study found that the increase of CASR was the result of PTHrP and NF- $\kappa \mathrm{B}$ upregulation, which was also positively correlated with bone metastasis in lung cancer $(173,175,176)$. This evidence attracted attention to CASR as a new biomarker for the prediction of lung cancer bone metastasis.

\section{Sclerostin Domain Containing 1 (SOSTDC1)}

SOSTDC1, secreted by particular helper T cells and reticular cells, plays a critical role in the development and progression of multiple types of cancer (177). Immunohistochemistry staining has indicated that SOSTDC1 is downregulated in NSCLC bone metastatic lesions compared with primary tumors (178). Moreover, Chen et al. (179) showed that overexpression of SOSTDC1 suppressed NSCLC migration, invasion, and osteoclast activity, whereas its knockdown led to the opposite effect. In addition, several downstream genes related to bone metastasis were detected using RNA-sequencing and quantitative RT-PCR (qRT-PCR) assays. Mechanistically, SOSTDC1 inhibits tumor progression by blocking the Wnt- $\beta$-catenin axis and facilitating $\mathrm{T}$ cell differentiation This finding suggests that SOSTDC1 is a potential prognostic biomarker for NSCLC bone metastasis (177).

\section{HECT and RLD Domain Containing E3 Ubiquitin Protein Ligase 5 (HERC5)}

HERC5 is a gene fragment located in the chromosome 4q22 and associated with the early presence of disseminated tumor cells in the bone marrow. Accumulating evidence has shown that the HERC protein family is a key component of a wide range of cellular functions, including neurodevelopment, DNA damage repair, cell growth, and immune response (180). Wrage et al. (181) initially found the same loss of chromosome 4q12-q32 in brain metastases from lung cancer. Subsequently, they narrowed this loss to gene HERC5 using qRT-PCR. In addition, hypermethylation of the HERC5 promoter was associated with poor survival in patients with early-stage and metastatic lung cancer. Thus, HERC5 was thought to be a new metastasis suppressor gene, whose methylation and expression status may provide prognostic information for bone metastasis of NSCLC.

\section{Cytokeratin 19 Fragment/ Carcinoembryonic Antigen (CYFRA/CEA)}

CYFRA is one of the characteristic markers for the diagnosis of NSCLC. CEA is also widely used in clinical practice as a serum marker for NSCLC. Recently, Numata et al. concluded that elevated serum CEA and CYFRA levels were associated with the presence of bone and liver metastasis and also multiple-organ metastases; however, these high levels were not a powerful indicator of prognosis (38). Furthermore, serum CEA and CYFRA had predictive value with regard to response to therapy in NSCLC, and decreased levels of CYFRA are indicative of objective response (182). Hence, CEA and CYFRA were utilized in some clinical research studies as positive contrast to other markers $(31,35)$. The use of CEA and CYFRA presents opportunities for risk stratification of patients and may aid in the clinical management of the disease.

\section{Tissue Factor (TF)}

$\mathrm{TF}$, produced during the development of embryo and normal hemostasis, plays an essential role in regulating platelet activation, fibrin deposition, and the extrinsic coagulation cascade by binding to factor VIIa (183). It has been demonstrated that TF-induced fibrin deposition was positively associated with tumor progression by affecting complement activation and the recruitment of myeloid-derived suppressor cells (184). Xia et al. (185) reported that patients with high TF expression levels tended to have worse OS, and downregulation of TF inhibited the invasion and migration of NSCLC cells in vitro and in vivo. This evidence suggests that TF is an effective biomarker for predicting the prognosis of patients with NSCLC.

\section{Cell-Free DNA (cfDNA)}

Nonencapsulated extracellular DNA fragments, termed cfDNA, have been found in body fluids. These fragments could also be narrowly defined as ctDNA in patients with solid malignancies $(186,187)$. cfDNA is thought to be generated during the process of cell apoptosis and necrosis, with a short half-life ranging $16 \mathrm{~min}-2.5$ $\mathrm{h}$. These features make it an ideal predictive biomarker for the early detection of lung cancer $(188,189)$. The use of cfDNA is attracting attention, as studies have shown that it can identify and differentiate the heterogeneous nature of different metastatic sites (190). Notably, higher concentrations of plasma cfDNA were detected in the peripheral blood of patients with bone metastasis. These higher levels are thought to be associated with an increased risk of distant migration and worse clinical outcome (191-193). Similarly, lung cancer patients without bone metastasis had significantly reduced urinary cfDNA and longer OS (194). Moreover, as the cfDNA turnaround time was significantly shorter than that of tissue-based genotyping, cfDNA was shown to be functional in the clinical management of the disease in the National Comprehensive Cancer Network (96).

In particular, cfDNA could be used as a non-invasive method to detect EGFR mutations in patients with NSCLC, with similar accuracy to that of tumor tissue biopsies. Dynamic changes in the cfDNA EGFR mutation status are associated with the clinical outcomes of treatment with EGFR-TKI (126, 195-199). 


\section{Long Non-Coding RNA (IncRNA)}

LncRNA are the products of DNA transcription with limited or no protein-coding capacities. However, lncRNA has a variety of functions in the regulation of biological processes, such as migration, proliferation, apoptosis, and invasion (200).
The expression levels of lncRNA in malignant tissues often differ significantly from those measured in normal tissues and correlate with tumor staging. Recently, studies utilizing high-throughput transcriptome analysis (RNA sequencing) indicated that lncRNA, including metastasis associated

TABLE 5 | Current studies on the efficacy of EGFR inhibitors in lung cancer.

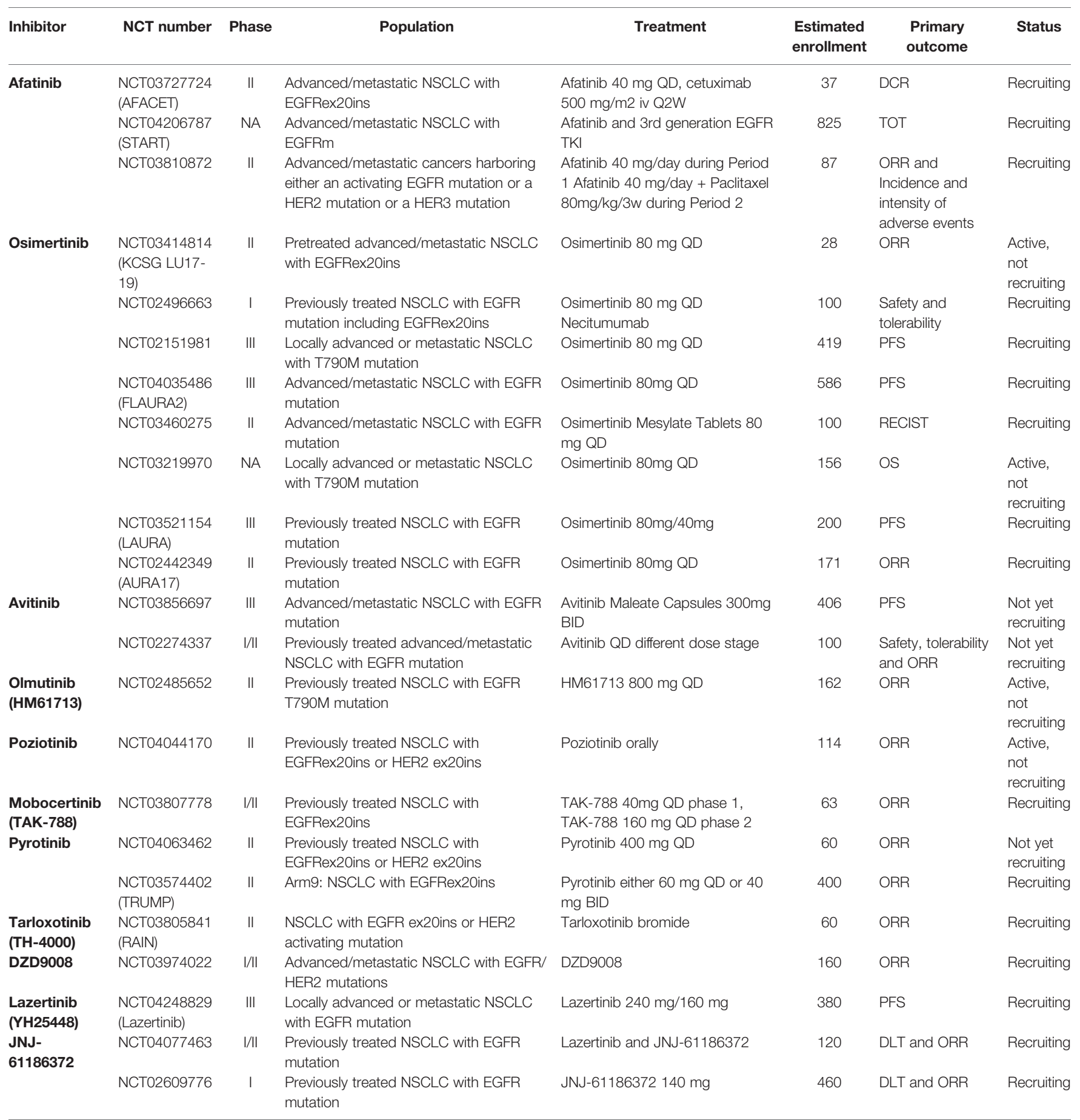

NSCLC, non-small cell lung cancer; EGFR, epidermal growth factor receptor; Ex, exon; Ins, insertion; HER2, human epidermal growth factor receptor2; Mut, mutation; QD, once daily; BID, twice daily; DCR, disease control rate; ORR, objective response rate; OS, overall survival; PFS, progression free survival; RECIST, response evaluation criteria in solid tumors; TOT, time on treatment; DLT, dose limiting toxicity. NA, missing value. 
lung adenocarcinoma transcript 1 (MALAT1), PXN-AS1-L, and SUMO1 pseudogene 3 (SUMO1P3), etc., were significantly highly expressed in NSCLC tissues with bone migration. These findings suggested that lncRNA are of great predictive value in bone metastasis (201-203). However, the specific mechanisms involved in this relationship remain unknown and require further studies. Li et al. demonstrated that the plasma levels of lncRNA HOX transcript antisense RNA (HOTAIR) were higher in NSCLC samples versus normal specimens (204). Thus, lncRNAs can be utilized as biomarkers in NSCLC with or without bone metastasis.

\section{MicroRNA (miRNA)}

MiRNAs are a class of small, single-stranded, no-coding RNAs, which were recently regarded a research hotspot. They act as gene regulator by binding to mRNAs and inhibiting their functions (205). Plenty of studies revealed that miRNAs play significant roles, including both oncogenes and tumor suppressors, during the progression and metastasis of lung cancer (206-208). Overexpression of the let-7 family, miR-486, miR-218, miR-34, and miR-200 were proved to inhibit the tumor cell proliferation, invasion and colony formation, though there is no specific article describing their relations with tumor cells bone migration (209212). In the opposite, some miRNAs take oncogenic roles, containing miR-196b, miR-221/222, miR-21, miR17/92, and miR-224 (213-218). The genetic alterations or epigenetic changes of miRNAs are closely implicated in the metastasis of NSCLC, which identify more target therapies for lung cancer bone metastasis.

\section{CURRENT AND NEXT GENERATION THERAPIES}

Currently, numerous promising drugs targeting biomarkers in patients with advanced/metastatic lung cancer carrying different mutations are under investigation. Clinical trials focusing on EGFR/ALK/KRAS, MET/HGF, and RANK/RANKL signaling have highlighted potential therapies for advanced NSCLC with or without distant metastasis. Ongoing clinical trials assessing the efficacy of EGFR inhibitors (afatinib, osimertinib, olmutinib, and poziotinib) and other newly developed drugs targeting ex20ins, T790, or other EGFR mutations are listed in Table 5.

Table 6 lists ongoing clinical trials assessing the efficacy of ALK inhibitors, including alectinib, brigatinib and lorlatinib which target advanced/metastatic ALK-positive NSCLC. Table 7 shows two ongoing clinical trials of AMG510 and MRTX849 targeting lung cancer patients with the KRAS G12C mutation. Table 8 summarizes information on ongoing clinical trials assessing the efficacy of MET inhibitors, such as cabozantinib, tepotinib, capmatinib, telisotuzumab, crizotinib, sacolitinib, and rilotumumab. Table 9 presents the ongoing clinical trials involving patients with bone metastatic NSCLC treated with the RANK-targeting denosumab. To some extent, these clinical trials offer opportunities for late-stage patients and those who cannot afford curative tumor resections.

There is no approved therapy targeting c-MET, while several c-MET inhibitors (e.g., crizotinib, cabozantinib, tepotinib, telisotuzumab, etc.) are being investigated in clinical trials. Table 10 presents the details of these clinical trials. According

TABLE 6 | Ongoing clinical trials assessing the efficacy of ALK inhibitors in lung cancer.

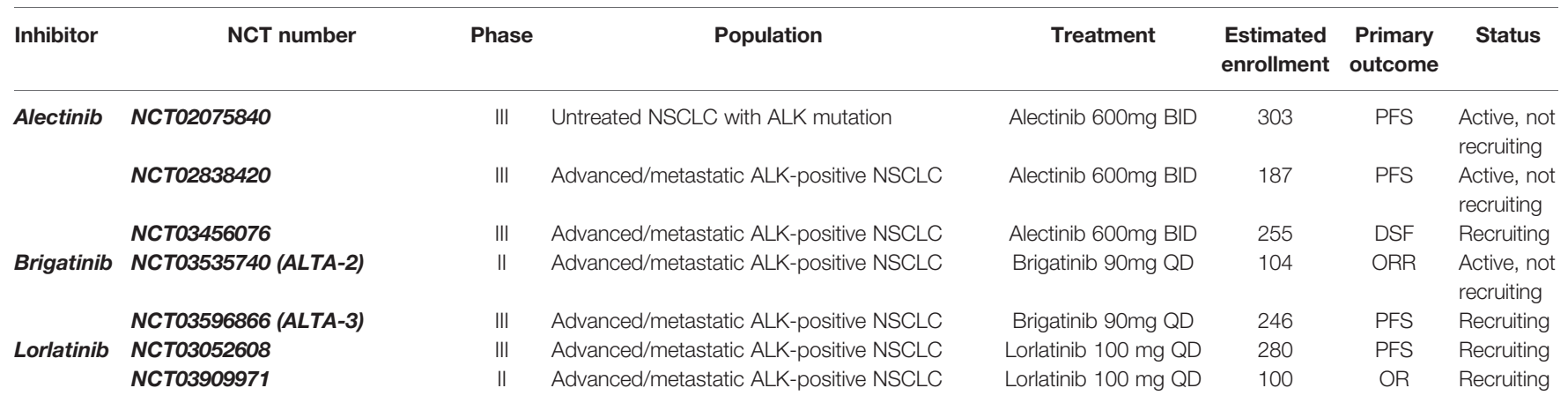

NSCLC, non-small cell lung cancer; ALK, anaplastic lymphoma kinase; QD, once daily; BID, twice daily; ORR, objective response rate; OS, overall survival; PFS, progression free survival; DSF, disease-free survival.

TABLE 7 | Ongoing clinical trials assessing the efficacy of KRAS inhibitors in lung cancer.

\begin{tabular}{|c|c|c|c|c|c|c|c|}
\hline Inhibitor & NCT number & Phase & Population & Treatment & $\begin{array}{l}\text { Estimated } \\
\text { enrollment }\end{array}$ & Primary outcome & Status \\
\hline AMG 510 & NCT04303780 & III & $\begin{array}{l}\text { Advanced/metastatic NSCLC with KRAS G12C } \\
\text { mutation }\end{array}$ & AMG 510 & 650 & PFS & Recruiting \\
\hline MRTX849 & NCT04330664 & $|/| \mid$ & Solid tumor malignancy with KRAS G12C mutation & MRTX849 & 148 & Safety and pharmacokinetics & Recruiting \\
\hline
\end{tabular}

NSCLC, non-small cell lung cancer; KRAS, kirsten rat sarcoma mutations; PFS, progression free survival. 
TABLE 8 | Ongoing clinical trials assessing the efficacy of MET inhibitors in lung cancer.

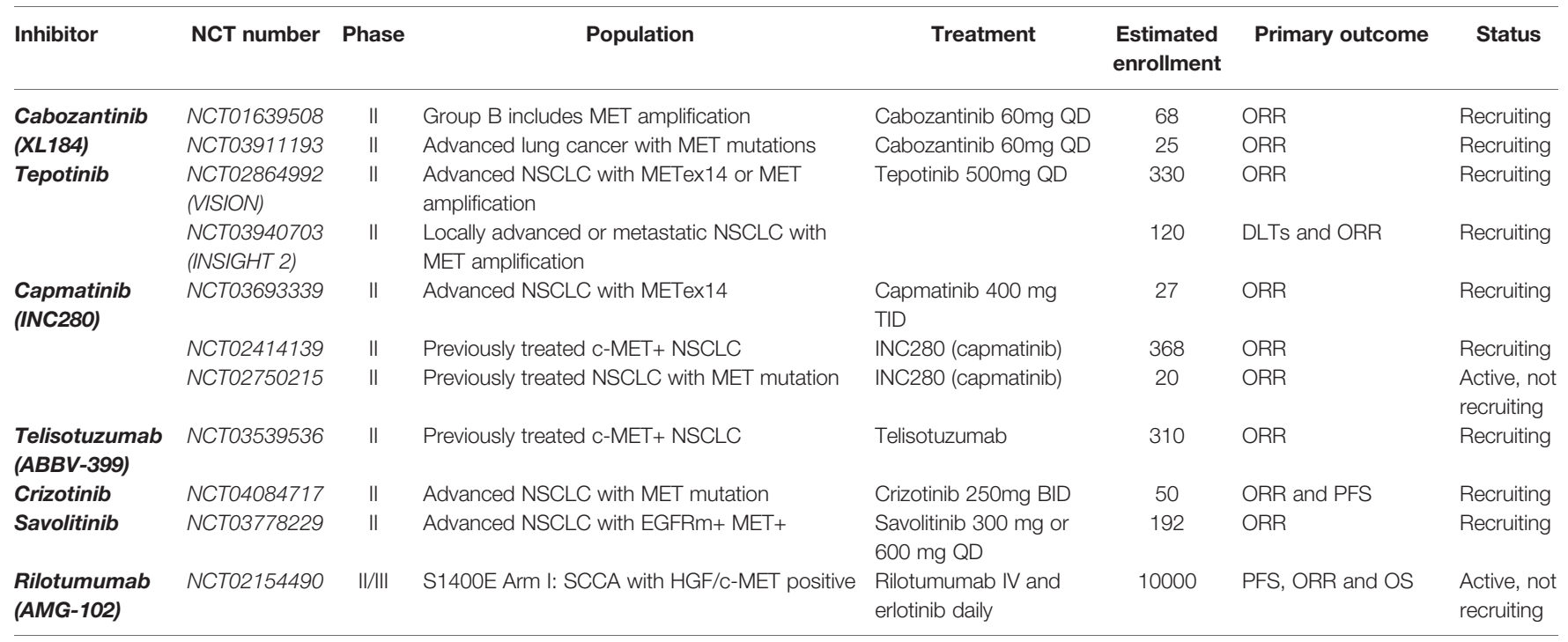

NSCLC, non-small cell lung cancer; MET, mesenchymal-epithelial transition factors; Ex, exon; Mut, mutation; QD, once daily; BID, twice daily; TID, third daily; ORR, objective response rate; OS, overall survival; PFS, progression free survival; DLT, dose limiting toxicity.

TABLE 9 | Ongoing clinical trials assessing the efficacy of RANK inhibitors in lung cancer.

\begin{tabular}{|c|c|c|c|c|c|c|c|}
\hline Inhibitor & NCT number & Phase & Population & Treatment & $\begin{array}{l}\text { Estimated } \\
\text { enrollment }\end{array}$ & Primary outcome & Status \\
\hline \multirow[t]{2}{*}{ Denosumab } & NCT03669523 & $\|$ & NSCLC with bone metastasis & $\begin{array}{l}\text { Denosumab } \\
\text { +nivolumab }\end{array}$ & 86 & ORR & Recruiting \\
\hline & NCT03958565 & NA & $\begin{array}{l}\text { Pathologically confirmed NSCLC with bone } \\
\text { metastasis but no driver oncogene }\end{array}$ & $\begin{array}{l}\text { Denosumab } \\
120 \mathrm{mg}\end{array}$ & 100 & $\begin{array}{l}\text { Percentage reduction of urine } \\
\text { NTx and serum CTx }\end{array}$ & Recruiting \\
\hline
\end{tabular}

NSCLC, non-small cell lung cancer; RANK, receptor activator of nuclear factor $\mathrm{kB}$; ORR, objective response rate.NA, missing value.

to a retrospective study, MET inhibitors are associated with prolonged OS of patients with metastatic METex14 NSCLC (130, 131). Secondary c-MET amplification is the most frequent cause of EGFR-TKIs tolerance. Following the administration of osimertinib as first-line therapy, MET amplification (encountered in $15 \%$ of patients) was the most common mechanism of intrinsic resistance (99). Moreover, $>50 \%$ of the EGFR T790M-positive patients retained the c-MET amplification, and c-MET mutations are likely to be associated with EGFR C797S, CDK6, and BRAF amplifications $(131,132)$. These phenomenon provide opportunities for the combined treatment of lung cancer patients.

For the future, therapies utilizing lncRNA is under development, which works by affecting transcriptome directly. Studies suggested that $\operatorname{lncRNA}$ was associated with resistance to both chemotherapy and targeted therapies (219). For example, lncRNA LINC00460 promotes EGFR expression by downregulating miR-769-5p, which results in the resistance of NSCLC cells to gefitinib (220). LncRNA MALAT1 upregulates multiple drug resistance-related protein (MDR1) and multidrug resistance protein (MDR1) by inducing STAT3 phosphorylation, which eventually enhance the resistance of lung cancer cells to treatment with cisplatin $(221,222)$. Though there is no specific clinical trial targeting lung cancer, it's still a potential therapy for the comprehensive treatment of lung cancer.

\section{CONCLUSION}

Patients with lung cancer bone metastasis rarely receive effective targeted therapy at an early stage due to delayed diagnosis. Therefore, the discovery of more accurate diagnostic methods is warranted. The bone formation and resorption markers have already been applied to clinical practice, and greatly aid in improving clinical management. For example, liquid biopsy of circulating tumor cancer, circulating cell-free nucleic acids, and extracellular vesicles are a promising source of prognostic and therapeutic biomarkers for metastatic lung cancer (223-225). However, thus far, most of the signaling axes and other markers remain under investigation without a recognized standard due to inconsistent results and methodological differences. To combine the advantages of these markers, some research studies utilized meta-analysis to identify clinical criteria and construct a clinical model. However, the limited number of samples and marker types restrict the reliability of this model (32, $52,74)$. Consequently, it is necessary to integrate clinical 
TABLE 10 | Current studies on other markers.

\begin{tabular}{|c|c|c|c|c|}
\hline Marker & Reference & $\begin{array}{l}\text { Sample } \\
\text { location }\end{array}$ & $\begin{array}{l}\text { Sample } \\
\text { size (N) }\end{array}$ & Finding \\
\hline CASR & $\begin{array}{l}\text { Liu et al. } \\
(174)\end{array}$ & $\begin{array}{l}\text { Tumor } \\
\text { tissue }\end{array}$ & 120 & $\begin{array}{l}\text { CASR expression in lung cancer tissues was significantly higher than that measured in adjacent and normal lung } \\
\text { tissues. The expression of CASR in lung cancer tissues with BM was higher than that observed in non-metastatic lung } \\
\text { cancer tissues. }\end{array}$ \\
\hline \multirow[t]{3}{*}{ BSP } & $\begin{array}{l}\text { Bellahcene } \\
\text { et al. (33) }\end{array}$ & $\begin{array}{l}\text { Primary } \\
\text { lung tumor } \\
\text { tissue }\end{array}$ & 86 & $\begin{array}{l}\text { BSP was not specifically detected in normal lung tissue with the exception of cartilage associated with bronchi. Most } \\
\text { adenocarcinoma (74\%) and all squamous carcinoma of the lung samples examined exhibited detectable levels of BSP. }\end{array}$ \\
\hline & $\begin{array}{l}\text { Zhang } \\
\text { et al. (70) }\end{array}$ & $\begin{array}{l}\text { Primary } \\
\text { lung tumor } \\
\text { tissue }\end{array}$ & 180 & $\begin{array}{l}\text { BSP protein expression in the primary resected NSCLC was strongly associated with BM and could be used to } \\
\text { identify high-risk patients after primary tumor resection. }\end{array}$ \\
\hline & $\begin{array}{l}\text { He et al. } \\
(71)\end{array}$ & Serum & 146 & $\begin{array}{l}\text { The mean serum BSP levels in individuals with BM were significantly higher than those recorded in non-BM NSCLC } \\
\text { and controls }(\mathrm{p}<0.001) \text {. The cut-off value was } 33.56 \mathrm{ng} / \mathrm{ml} \text {, and sensitivity and specificity values were } 77.8 \% \text { and } \\
81.1 \% \text {, respectively. }\end{array}$ \\
\hline \multirow[t]{4}{*}{ BMP2 } & $\begin{array}{l}\text { Bieniasz } \\
\text { et al. (168) }\end{array}$ & $\begin{array}{l}\text { Tumor } \\
\text { tissue }\end{array}$ & & $\begin{array}{l}\text { The expression levels of VEGF, BMP2, and BMP4 mRNA were significantly higher (7.1-fold, 25.6-fold, and 2.3-fold, } \\
\text { respectively) in lung cancer samples than those in adjacent normal lung tissues. }\end{array}$ \\
\hline & $\begin{array}{l}\text { Choi et al. } \\
(169)\end{array}$ & Serum & 150 & $\begin{array}{l}\text { The NSCLC group demonstrated significantly higher levels of serum BMP2 than the control group. The median serum } \\
\text { levels of BMP2 in the advanced stage group (stage IIIb or IV) were significantly elevated compared with those of the } \\
\text { localized stage group (stages I, II, and IIla). }\end{array}$ \\
\hline & $\begin{array}{l}\text { Fei et al. } \\
(170)\end{array}$ & Serum & 84 & $\begin{array}{l}\text { Serum BMP2 levels were significantly decreased in patients who achieved objective response after two cycles of } \\
\text { chemotherapy. }\end{array}$ \\
\hline & $\begin{array}{l}\text { Huang } \\
\text { et al. (171) }\end{array}$ & $\begin{array}{l}\text { Tumor } \\
\text { tissue }\end{array}$ & $\begin{array}{l}\text { in vivo } \\
\text { study }\end{array}$ & Activation of BMP2 signaling can enhance BM of Lewis lung carcinoma. \\
\hline $\begin{array}{l}\text { CYFRA } \\
\text { and CEA }\end{array}$ & $\begin{array}{l}\text { Numata } \\
\text { et al. (182) }\end{array}$ & $\begin{array}{l}\text { Serum/ } \\
\text { tumor } \\
\text { tissue }\end{array}$ & 131 & $\begin{array}{l}\text { Elevated serum CEA and CYFRA levels appear to provide useful clinical information on the presence of BM and liver } \\
\text { metastasis, as well as multiple-organ metastases, although they were not a powerful indicator of prognosis. }\end{array}$ \\
\hline $\begin{array}{l}\text { Tissue } \\
\text { factor }\end{array}$ & $\begin{array}{l}\text { Xia et al. } \\
(186)\end{array}$ & Serum & 100 & $\begin{array}{l}\text { Patients with high tissue factor expression levels tended to have worse overall survival performance, and } \\
\text { downregulation of tissue factor inhibited the invasion and metastasis of NSCLC cells in vitro and in vivo. }\end{array}$ \\
\hline $\begin{array}{l}\text { Cell-free } \\
\text { DNA }\end{array}$ & $\begin{array}{l}\text { Pecuchet } \\
\text { et al. (192) }\end{array}$ & Serum & 124 & The presence of circulating tumor DNA at baseline was an independent marker of poor prognosis. \\
\hline \multirow[t]{2}{*}{ (cfDNA) } & $\begin{array}{l}\text { Ettinger } \\
\text { et al. (83) }\end{array}$ & Serum & 282 & DNA median turnaround time was significantly shorter than that of tissue ( 9 vs. 15 days, respectively; $p<0.0001$ ) \\
\hline & $\begin{array}{l}\text { Ye et al. } \\
(193)\end{array}$ & $\begin{array}{l}\text { Tumor } \\
\text { tissue }\end{array}$ & 186 & Patients with BM had higher concentrations of cfDNA and worse survival outcome. \\
\hline
\end{tabular}

BM, bone metastasis; BMP2, bone morphogenetic protein 2; BSP, bone sialoprotein; CASR, calcium sensing receptor; CEA, carcinoembryonic antigen; CYFRA, cytokeratin 19 fragment; NSCLC, non-small-cell lung cancer; VEGF, vascular endothelial growth factor.

resources and utilize larger sample sizes, as well as unified standards for the selection of patients and evaluation of bone metastasis and clinical outcomes. This approach would allow researchers to determine the ideal, inexpensive biomarkers for the evaluation of skeletal metastasis and skeletal-related events. Moreover, combination therapies targeting these biomarkers are currently under investigation in clinical trials. Based on the available evidence regarding these biomarkers, the prognosis of treatment using targeted therapies is promising. Further studies concerning the mechanisms of these biomarkers will contribute to the development of effective therapies against bone metastasis.

\section{AUTHOR CONTRIBUTIONS}

$\mathrm{XC}, \mathrm{EY}$ and $\mathrm{ZeW}$ wrote the manuscript. $\mathrm{ZhW}, \mathrm{BL}$, and $\mathrm{YZ}$ provided expertise and advice. HZ, YWE, SW and WZ critically read the manuscript. ZY supervised the project. All

\section{REFERENCES}

1. Jemal A, Bray F, Center M, Ferlay J, Ward E, Forman D. Global Cancer Statistics. CA: Cancer J Clin (2011) 61(2):69-90. doi: 10.3322/ caac. 20107 authors contributed to the article and approved the submitted version.

\section{FUNDING}

This work was supported by National Natural Science Foundation of China (81872173, 82072959); Natural Science Foundation of Zhejiang province, China (LD21H160002); Medical and Health Science and Technology Plan of Department of Health of Zhejiang Province (WKJ-ZJ-1821).

\section{ACKNOWLEDGMENTS}

We would like to thank Dr. Binghao Li, Dr. Zhan Wang and Dr. Yongxing Zhang for critical reading of the manuscript.

2. Coleman R. Clinical Features of Metastatic Bone Disease and Risk of Skeletal Morbidity. Clin Cancer Res an Off J Am Assoc Cancer Res (2006) 12:6243s-9s. doi: 10.1158/1078-0432.CCR-06-0931

3. Coleman R, Body J, Aapro M, Hadji P, Herrstedt J. Bone Health in Cancer Patients: ESMO Clinical Practice Guidelines. Ann 
Oncol Off J Eur Soc Med Oncol (2014) iii124-37. doi: 10.1093/annonc/ mdu 103

4. Saad F, Lipton A, Cook R, Chen Y, Smith M, Coleman R. Pathologic Fractures Correlate With Reduced Survival in Patients With Malignant Bone Disease. Cancer (2007) 110(8):1860-7. doi: 10.1002/cncr.22991

5. Scagliotti GV, Hirsh V, Siena S, Henry DH, Woll PJ, Manegold C, et al. Overall Survival Improvement in Patients With Lung Cancer and Bone Metastases Treated With Denosumab Versus Zoledronic Acid: Subgroup Analysis From a Randomized Phase 3 Study. J Thorac Oncol (2012) 7 (12):1823-9. doi: 10.1097/JTO.0b013e31826aec2b

6. Henry DH, Costa L, Goldwasser F, Hirsh V, Hungria V, Prausova J, et al. Randomized, Double-Blind Study of Denosumab Versus Zoledronic Acid in the Treatment of Bone Metastases in Patients With Advanced Cancer (Excluding Breast and Prostate Cancer) or Multiple Myeloma. J Clin Oncol (2011) 29(9):1125-32. doi: 10.1200/JCO.2010.31.3304

7. Miyashita H, Cruz C, Smith C. Risk Factors of Skeletal-Related Events in Patients With Bone Metastasis From Non-Small Cell Lung Cancer Undergoing Treatment With Zoledronate-A Post Hoc Analysis of a Randomized Clinical Trial. Support Care Cancer (2020). doi: 10.26226/ morressier.5ebc4ac6ffea6f735881a424

8. Wu Y, Planchard D, Lu S, Sun H, Yamamoto N, Kim D, et al. Pan-Asian Adapted Clinical Practice Guidelines for the Management of Patients With Metastatic Non-Small-Cell Lung Cancer: A CSCO-ESMO Initiative Endorsed by JSMO, KSMO, MOS, SSO and TOS. Ann Oncol Off J Eur Soc Med Oncol (2019) 30(2):171-210. doi: 10.1093/annonc/mdy554

9. Planchard D, Popat S, Kerr K, Novello S, Smit E, Faivre-Finn C, et al. Metastatic Non-Small Cell Lung Cancer: ESMO Clinical Practice Guidelines for Diagnosis, Treatment and Follow-Up. Ann Oncol Off J Eur Soc Med Oncol (2018) 29:iv192-237. doi: 10.1093/annonc/mdy275

10. Fischer B, Mortensen J, Langer S, Loft A, Berthelsen A, Petersen B, et al. A Prospective Study of PET/CT in Initial Staging of Small-Cell Lung Cancer: Comparison With CT, Bone Scintigraphy and Bone Marrow Analysis. Ann Oncol Off J Eur Soc Med Oncol (2007) 18(2):338-45. doi: 10.1093/annoncl $\mathrm{mdl} 374$

11. Lee J, Lee S, Lee H, Kim Y, Bae W. Comparison of Diagnostic Ability Between (99m)Tc-MDP Bone Scan and (18)F-FDG PET/CT for Bone Metastasis in Patients With Small Cell Lung Cancer. Ann Nucl Med (2012) 26(8):627-33. doi: 10.1007/s12149-012-0622-3

12. Wang H, Zhang Y, Zhu H, Yu J. Risk Factors for Bone Metastasis in Completely Resected Non-Small-Cell Lung Cancer. Future Oncol (2017) 13 (8):695-704. doi: 10.2217/fon-2016-0237

13. Zang S, He Q, Bao Q, Shen Y, Zhang W. Establishment and Validation of a Novel Survival Prediction Scoring Algorithm for Patients With Non-SmallCell Lung Cancer Spinal Metastasis. Int J Clin Oncol (2019) 24(9):1049-60. doi: 10.1007/s10147-019-01452-8

14. Santini D, Daniele S, Barni S, Sandro B, Intagliata S, Salvatore I, et al. Natural History of Non-Small-Cell Lung Cancer With Bone Metastases. Sci Rep (2015) 5:18670. doi: 10.1038/srep18670

15. Yang J, Peng A, Wang B, Gusdon AM, Sun X, Jiang G, et al. The Prognostic Impact of Lymph Node Metastasis in Patients With Non-Small Cell Lung Cancer and Distant Organ Metastasis. Clin Exp Metastasis (2019) 36(5):45766. doi: 10.1007/s10585-019-09985-y

16. Topalian SL, Hodi FS, Brahmer JR, Gettinger SN, Smith DC, McDermott DF, et al. Safety, Activity, and Immune Correlates of Anti-PD-1 Antibody in Cancer. N Engl J Med (2012) 366(26):2443-54. doi: 10.1056/NEJMoa1200690

17. Borghaei H, Paz-Ares L, Horn L, Spigel DR, Steins M, Ready NE, et al. Nivolumab Versus Docetaxel in Advanced Nonsquamous Non-Small-Cell Lung Cancer. N Engl J Med (2015) 373(17):1627-39. doi: 10.1056/ NEJMoa1507643

18. Wang H, Agulnik J, Kasymjanova G, Fiset PO, Camilleri-Broet S, Redpath $\mathrm{M}$, et al. The Metastatic Site Does Not Influence PD-L1 Expression in Advanced Non-Small Cell Lung Carcinoma. Lung Cancer (2019) 132:36-8. doi: 10.1016/j.lungcan.2019.04.009

19. Ricciuti B, Kravets S, Dahlberg SE, Umeton R, Albayrak A, Subegdjo SJ, et al. Use of Targeted Next Generation Sequencing to Characterize Tumor Mutational Burden and Efficacy of Immune Checkpoint Inhibition in Small Cell Lung Cancer. J Immunother Cancer (2019) 7(1):87. doi: 10.1186/s40425-019-0572-6
20. Shibata H, Kato S, Sekine I, Abe K, Araki N, Iguchi H, et al. Diagnosis and Treatment of Bone Metastasis: Comprehensive Guideline of the Japanese Society of Medical Oncology, Japanese Orthopedic Association, Japanese Urological Association, and Japanese Society for Radiation Oncology. ESMO Open (2016) 1(2):e000037. doi: 10.1136/esmoopen-2016-000037

21. Fornetti J, Welm A, Stewart S. Understanding the Bone in Cancer Metastasis. J Bone Mineral Res Off J Am Soc Bone Mineral Res (2018) 33 (12):2099-113. doi: 10.1002/jbmr.3618

22. Wood S, Pernemalm M, Crosbie P, Whetton A. The Role of the TumorMicroenvironment in Lung Cancer-Metastasis and Its Relationship to Potential Therapeutic Targets. Cancer Treat Rev (2014) 40(4):558-66. doi: 10.1016/j.ctrv.2013.10.001

23. Jablonka F, Schindler F, Lajolo P, Pinczowski H, Fonseca F, Barbieri A, et al. Serum Cross-Linked N-Telopeptides of Type 1 Collagen (NTx) in Patients With Solid Tumors. Sao Paulo Med J = Rev Paulista Medicina (2009) 127 (1):19-22. doi: 10.1590/S1516-31802009000100005

24. Sugiura H, Yamada K, Sugiura T, Hida T, Mitsudomi T. Predictors of Survival in Patients With Bone Metastasis of Lung Cancer. Clin orthopaedics related Res (2008) 466(3):729-36. doi: 10.1007/s11999-007-0051-0

25. Izumi M, Nakanishi $Y$, Takayama K, Kimotsuki K, Inoue K, Wataya $H$, et al. Diagnostic Value of Bone-Turnover Metabolites in the Diagnosis of Bone Metastases in Patients With Lung Carcinoma. Cancer (2001) 91 (8):1487-93. doi: 10.1002/1097-0142(20010415)91:8<1487::AIDCNCR1156>3.0.CO;2-2

26. Chung J, Park M, Kim Y, Chang J, Kim J, Kim S, et al. Usefulness of Bone Metabolic Markers in the Diagnosis of Bone Metastasis From Lung Cancer. Yonsei Med J (2005) 46(3):388-93. doi: 10.3349/ymj.2005.46.3.388

27. Lumachi F, Basso SMM, Marino F, Ambrosino G, Polistina F. 61pd Serum N-Telopeptide of Type I Collagen and Bone Alkaline Phosphatase and Their Relationship in Patient With Non-Small Cell Lung Carcinoma and Bone Metastases. Lung Cancer (2011) 71. doi: 10.1016/S0169-5002(11)70198-2

28. Bayrak SB, Ceylan E, Serter M, Karadag F, Demir E, Cildag O. The Clinical Importance of Bone Metabolic Markers in Detecting Bone Metastasis of Lung Cancer. Int J Clin Oncol (2012) 17(2):112-8. doi: 10.1007/s10147-0110266-7

29. Kaira R, Murakami H, Kaira K, Takahashi T, Tsuya A, Nakamura Y, et al. NTelopeptide of Type I Collagen Is Useful for Monitoring Therapeutic Response in Non-Small Cell Lung Cancer Patients With Bone Metastases. Int J Clin Oncol (2010) 15(5):484-8. doi: 10.1007/s10147-010-0100-7

30. Zhang Y, Yi M, Cao J, Hou C, Zhou Y, Zhong Y. Serum Cross-Linked NTelopeptide of Type I Collagen for the Diagnosis of Bone Metastases From Solid Tumours in the Chinese Population: Meta-Analysis. J Int Med Res (2016) 44(2):192-200. doi: 10.1177/0300060515600187

31. Horiguchi T, Tachikawa S, Kondo R, Hirose M, Teruya S, Ishibashi A, et al. Usefulness of Serum Carboxy-Terminal Telopeptide of Type I Collagen (ICTP) as a Marker of Bone Metastasis From Lung Cancer. Jpn J Clin Oncol (2000) 30(4):174-9. doi: 10.1093/jico/hyd043

32. Huang J, Gu T, Ying J. A Meta-Analysis Survey of Appropriate Bone Turnover Markers in the Detection of Bone Metastasis in Lung Cancer. Int J Clin Oncol (2017) 22(6):1015-25. doi: 10.1007/s10147-017-1159-1

33. Tang C, Liu Y, Qin H, Li X, Guo W, Li J, et al. Clinical Significance of Serum BAP, TRACP 5b and ICTP as Bone Metabolic Markers for Bone Metastasis Screening in Lung Cancer Patients. Clin Chim Acta (2013) 426:102-7. doi: 10.1016/j.cca.2013.09.011

34. Yokoyama T, Yamamoto M, Shima K, Suzuki K, Sako C, Ito G, et al. Clinical Usefulness of Serum Pyridinoline Cross-Linked Carboxyterminal Telopeptide of Type I Collagen for Diagnosis of Bone Metastases in Patients With Primary Lung Cancer. Respirology (2005) 10(3):300-4. doi: 10.1111/j.1440-1843.2005.00713.x

35. Tanaka Y, Yoshimasu T, Oura S, Hirai Y, Kawago M, Ikeda M, et al. Preoperative Serum Pyridinoline Cross-Linked Carboxy-Terminal Telopeptide of Type I Collagen Level Predicts Postoperative Distant Metastasis in Patients With Non-Small-Cell Lung Cancer. Eur J CardioThoracic Surg Off J Eur Assoc Cardio-Thoracic Surg (2013) 44(3):539-43; discussion 543. doi: 10.1093/ejcts/ezt076

36. Chrapko B, Nocuń A, Gołebiewska R, Jankowska H, Zaorska-Rajca J. Bone Turnover Markers and Bone Scintigraphy in the Evaluation of the Skeletal Metastases. Nucl Med Rev Cent Eastern Europe (2005) 8(2):100-4. 
37. Kong Q, Sun T, Dou Q, Li F, Tang Q, Pei F, et al. Beta-CTX and ICTP Act as Indicators of Skeletal Metastasis Status in Male Patients With Non-Small Cell Lung Cancer. Int J Biol Markers (2007) 22(3):214-20. doi: 10.5301/ JBM.2008.3777

38. Numata T, Endo T, Yanai H, Ota K, Yamamoto Y, Shimizu K, et al. Serum CEA and CYFRA Levels in ALK-Rearranged NSCLC Patients: Correlation With Distant Metastasis. In Vivo (Athens Greece) (2020) 34(4):2095-100. doi: 10.21873/invivo.12013

39. Chao TY, Wu YY, Janckila AJ. Tartrate-Resistant Acid Phosphatase Isoform $5 \mathrm{~b}$ (TRACP 5b) as a Serum Maker for Cancer With Bone Metastasis. Clin Chim Acta (2010) 411(21-22):1553-64. doi: 10.1016/j.cca.2010.06.027

40. Chao T, Yu J, Ku C, Chen M, Lee S, Janckila A, et al. Tartrate-Resistant Acid Phosphatase $5 \mathrm{~b}$ Is a Useful Serum Marker for Extensive Bone Metastasis in Breast Cancer Patients. Clin Cancer Res an Off J Am Assoc Cancer Res (2005) 11:544-50.

41. Hegele A, Wahl H, Varga Z, Sevinc S, Koliva L, Schrader A, et al. Biochemical Markers of Bone Turnover in Patients With Localized and Metastasized Prostate Cancer. BJU Int (2007) 99(2):330-4. doi: 10.1111/ j.1464-410X.2006.06604.x

42. Ebert W, Muley T, Herb K, Schmidt-Gayk H. Comparison of Bone Scintigraphy With Bone Markers in the Diagnosis of Bone Metastasis in Lung Carcinoma Patients. Anticancer Res (2004) 24:3193-201.

43. Karapanagiotou E, Terpos E, Dilana K, Alamara C, Gkiozos I, Polyzos A, et al. Serum Bone Turnover Markers may be Involved in the Metastatic Potential of Lung Cancer Patients. Med Oncol (Northwood London England) (2010) 27(2):332-8. doi: 10.1007/s12032-009-9214-z

44. Terpos E, Kiagia M, Karapanagiotou E, Charpidou A, Dilana K, Nasothimiou E, et al. The Clinical Significance of Serum Markers of Bone Turnover in NSCLC Patients: Surveillance, Management and Prognostic Implications. Anticancer Res (2009) 29(5):1651-7.

45. Robins S, Black D, Paterson C, Reid D, Duncan A, Seibel M. Evaluation of Urinary Hydroxypyridinium Crosslink Measurements as Resorption Markers in Metabolic Bone Diseases. Eur J Clin Invest (1991) 21(3):310-5. doi: $10.1111 / \mathrm{j} .1365-2362.1991 . t b 01375 . \mathrm{x}$

46. Coleman R, Houston S, James I, Rodger A, Rubens R, Leonard R, et al. Preliminary Results of the Use of Urinary Excretion of Pyridinium Crosslinks for Monitoring Metastatic Bone Disease. Br J Cancer (1992) 65 (5):766-8. doi: 10.1038/bjc.1992.161

47. Dane F, Turk A, Buyukberber S, Camci C. The Markers of Bone Turnover in Patients With Lung Cancer. J Natl Med Assoc (2008) 100(4):425-8. doi: 10.1016/S0027-9684(15)31276-1

48. Sone S, Yano S. Molecular Pathogenesis and Its Therapeutic Modalities of Lung Cancer Metastasis to Bone. Cancer Metastasis Rev (2007) 26:685-9. doi: 10.1007/s10555-007-9081-z

49. Miki T, Yano S, Hanibuchi M, Kanematsu T, Muguruma H, Sone S. Parathyroid Hormone-Related Protein (PTHrP) Is Responsible for Production of Bone Metastasis, But Not Visceral Metastasis, by Human Small Cell Lung Cancer SBC-5 Cells in Natural Killer Cell-Depleted SCID Mice. Int J Cancer (2004) 108(4):511-5. doi: 10.1002/ijc.11586

50. Katseli A, Maragos H, Nezos A, Syrigos K, Koutsilieris M. Multiplex PCRBased Detection of Circulating Tumor Cells in Lung Cancer Patients Using CK19, PTHrP, and LUNX Specific Primers. Clin Lung Cancer (2013) 14 (5):513-20. doi: 10.1016/j.cllc.2013.04.007

51. Deng X, Tannehill-Gregg S, Nadella M, He G, Levine A, Cao Y, et al. Parathyroid Hormone-Related Protein and Ezrin Are Up-Regulated in Human Lung Cancer Bone Metastases. Clin Exp Metastasis (2007) 24 (2):107-19. doi: 10.1007/s10585-007-9059-9

52. Teng X, Wei L, Han L, Min D, Du Y. Establishment of a Serological Molecular Model for the Early Diagnosis and Progression Monitoring of Bone Metastasis in Lung Cancer. BMC Cancer (2020) 20(1):562. doi: 10.1186/s12885-020-07046-2

53. Furugaki K, Moriya Y, Iwai T, Yorozu K, Yanagisawa M, Kondoh K, et al. Erlotinib Inhibits Osteolytic Bone Invasion of Human Non-Small-Cell Lung Cancer Cell Line NCI-H292. Clin Exp Metastasis (2011) 28(7):649-59. doi: 10.1007/s10585-011-9398-4

54. Muguruma H, Yano S, Kakiuchi S, Uehara H, Kawatani M, Osada H, et al. Reveromycin A Inhibits Osteolytic Bone Metastasis of Small-Cell Lung Cancer
Cells, SBC-5, Through an Antiosteoclastic Activity. Clin Cancer Res an Off J Am Assoc Cancer Res (2005) 11:8822-8. doi: 10.1158/1078-0432.CCR-05-1335

55. Peng X, Guo W, Ren T, Lou Z, Lu X, Zhang S, et al. Differential Expression of the RANKL/RANK/OPG System Is Associated With Bone Metastasis in Human Non-Small Cell Lung Cancer. PloS One (2013) 8(3):e58361. doi: 10.1371/journal.pone.0058361

56. Boyle W, Simonet W, Lacey D. Osteoclast Differentiation and Activation. Nature (2003) 423(6937):337-42. doi: 10.1038/nature01658

57. McGrath E. OPG/RANKL/RANK Pathway as a Therapeutic Target in Cancer. J Thorac Oncol Off Publ Int Assoc Study Lung Cancer (2011) 6 (9):1468-73. doi: 10.1097/JTO.0b013e318229421f

58. Boyce B, Xing L. Functions of RANKL/RANK/OPG in Bone Modeling and Remodeling. Arch Biochem Biophysics (2008) 473(2):139-46. doi: 10.1016/ j.abb.2008.03.018

59. Santini D, Perrone G, Roato I, Godio L, Pantano F, Grasso D, et al. Expression Pattern of Receptor Activator of Nfkb (RANK) in a Series of Primary Solid Tumors and Related Bone Metastases. J Cell Physiol (2011) 226(3):780-4. doi: 10.1002/jcp.22402

60. Zang L, Ma M, Hu J, Qiu H, Huang B, Chu T. The Effects of Lung and Prostate Cancer Bone Metastasis on Serum Osteoprotegerin Levels: A MetaAnalysis. Sci Rep (2015) 5(1). doi: 10.1038/srep18324

61. Ibrahim T, Ricci M, Scarpi E, Bongiovanni A, Ricci R, Riva N, et al. RANKL: A Promising Circulating Marker for Bone Metastasis Response. Oncol Lett (2016) 12(4):2970-5. doi: 10.3892/ol.2016.4977

62. Stopeck A, Lipton A, Body J, Steger G, Tonkin K, de Boer R, et al. Denosumab Compared With Zoledronic Acid for the Treatment of Bone Metastases in Patients With Advanced Breast Cancer: A Randomized, Double-Blind Study. J Clin Oncol Off J Am Soc Clin Oncol (2010) 28 (35):5132-9. doi: 10.1200/JCO.2010.29.7101

63. Raje N, Terpos E, Willenbacher W, Shimizu K, García-Sanz R, Durie B, et al. Denosumab Versus Zoledronic Acid in Bone Disease Treatment of Newly Diagnosed Multiple Myeloma: An International, Double-Blind, DoubleDummy, Randomised, Controlled, Phase 3 Study. Lancet Oncol (2018) 19 (3):370-81. doi: 10.1016/S1470-2045(18)30072-X

64. Lipton A, Fizazi K, Stopeck A, Henry D, Smith M, Shore N, et al. Effect of Denosumab Versus Zoledronic Acid in Preventing Skeletal-Related Events in Patients With Bone Metastases by Baseline Characteristics. Eur J Cancer (Oxford Engl 1990) (2016) 53:75-83. doi: 10.1016/j.ejca.2015.09.011

65. Fizazi K, Carducci M, Smith M, Damião R, Brown J, Karsh L, et al. Denosumab Versus Zoledronic Acid for Treatment of Bone Metastases in Men With Castration-Resistant Prostate Cancer: A Randomised, DoubleBlind Study. Lancet (Lond Engl) (2011) 377(9768):813-22. doi: 10.1016/ S0140-6736(10)62344-6

66. Peters S, Danson S, Hasan B, Dafni U, Reinmuth N, Majem M, et al. A Randomized Open-Label Phase III Trial Evaluating the Addition of Denosumab to Standard First-Line Treatment in Advanced NSCLC: The European Thoracic Oncology Platform (ETOP) and European Organisation for Research and Treatment of Cancer (EORTC) SPLENDOUR Trial. J Thorac Oncol Off Publ Int Assoc Study Lung Cancer (2020) 15(10):164756. doi: $10.1016 /$ j.jtho.2020.06.011

67. Wang M, Chao C-C, Chen P-C, Liu P-I, Yang Y-C, Su C-M, et al. Thrombospondin Enhances RANKL-Dependent Osteoclastogenesis and Facilitates Lung Cancer Bone Metastasis. Biochem Pharmacol (2019) 166:23-32. doi: 10.1016/j.bcp.2019.05.005

68. Aruga A, Koizumi M, Hotta R, Takahashi S, Ogata E. Usefulness of Bone Metabolic Markers in the Diagnosis and Follow-Up of Bone Metastasis From Lung Cancer. Br J Cancer (1997) 76(6):760-4. doi: 10.1038/ bjc. 1997.458

69. Lumachi F, Marino F, Fanti G, Chiara G, Basso S. Serum N-Telopeptide of Type I Collagen and Bone Alkaline Phosphatase and Their Relationship in Patients With Non-Small Cell Lung Carcinoma and Bone Metastases. Preliminary Results. Anticancer Res (2011) 31(11):3879-81. doi: 10.1016/ S0169-5002(11)70198-2

70. Behnke B, Kemper M, Kruse H, Müller-Wiefel D. Bone Alkaline Phosphatase in Children With Chronic Renal Failure. Nephrol dialysis Transplant Off Publ Eur Dialysis Transplant Assoc - Eur Renal Assoc (1998) 13(3):662-7. doi: 10.1093/ndt/13.3.662 
71. Ureña P, De Vernejoul M. Circulating Biochemical Markers of Bone Remodeling in Uremic Patients. Kidney Int (1999) 55(6):2141-56.

72. Bailey S, Karsenty G, Gundberg C, Vashishth D. Osteocalcin and Osteopontin Influence Bone Morphology and Mechanical Properties. Ann N Y Acad Sci (2017) 1409(1):79-84. doi: 10.1111/nyas.13470

73. Jin Y, Tong D, Tang L, Chen J, Zhou J, Feng Z, et al. Expressions of Osteopontin (OPN), $\alpha v \beta 3$ and Pim-1 Associated With Poor Prognosis in Non-Small Cell Lung Cancer (NSCLC). Chin J Cancer Res = Chung-kuo yen cheng yen chiu (2012) 24(2):103-8. doi: 10.1007/s11670-012-0103-1

74. Zhou Z, Chen Z, Yang X, Shen L, Ai X, Lu S, et al. Establishment of a Biomarker Model for Predicting Bone Metastasis in Resected Stage III NonSmall Cell Lung Cancer. J Exp Clin Cancer Res CR (2012) 31:34. doi: 10.1186/ 1756-9966-31-34

75. Chen Y, Liu H, Wu W, Li Y, Li J. Osteopontin Genetic Variants Are Associated With Overall Survival in Advanced Non-Small-Cell Lung Cancer Patients and Bone Metastasis. J Exp Clin Cancer Res CR (2013) 32:45. doi: 10.1186/1756-9966-32-45

76. Dieterly A, Uzunalli G, Kemet C, Soepriatna A, Goergen C, Lyle L. Epithelial-Mesenchymal Transition Phenotypes in Vertebral Metastases of Lung Cancer. Toxicologic Pathol (2019) 47(4):515-27. doi: 10.1177/ 0192623319838491

77. Liu Y, Qing H, Su X, Wang C, Li Z, Liu S. Association of CD44 Gene Polymorphism With Survival of NSCLC and Risk of Bone Metastasis. Med Sci monitor Int Med J Exp Clin Res (2015) 21:2694-700. doi: 10.12659/ MSM. 894357

78. Li J, Hsieh M, Chou Y, Chao Y, Tsao T, Yang S. CD44 Gene Polymorphisms as a Risk Factor for Susceptibility and Their Effect on the Clinicopathological Characteristics of Lung Adenocarcinoma in Male Patients. Int J Environ Res Public Health (2020) 17(9). doi: 10.3390/ijerph17092981

79. Kobayashi T, Gabazza E, Taguchi O, Risteli J, Risteli L, Kobayashi H, et al. Type I Collagen Metabolites as Tumor Markers in Patients With Lung Carcinoma. Cancer (1999) 85(9):1951-7. doi: 10.1002/(SICI) 1097-0142 (19990501)85:9<1951::AID-CNCR11>3.0.CO;2-H

80. Lüftner D, Jozereau D, Schildhauer S, Geppert R, Müller C, Fiolka G, et al. PINP as Serum Marker of Metastatic Spread to the Bone in Breast Cancer Patients. Anticancer Res (2005) 25:1491-9.

81. Esposito M, Kang Y. Targeting Tumor-Stromal Interactions in Bone Metastasis. Pharmacol Ther (2014) 141(2):222-33. doi: 10.1016/ j.pharmthera.2013.10.006

82. Bellahcène A, Maloujahmoum N, Fisher L, Pastorino H, Tagliabue E, Ménard S, et al. Expression of Bone Sialoprotein in Human Lung Cancer. Calcified Tissue Int (1997) 61(3):183-8.

83. Zhang L, Hou X, Lu S, Rao H, Hou J, Luo R, et al. Predictive Significance of Bone Sialoprotein and Osteopontin for Bone Metastases in Resected Chinese Non-Small-Cell Lung Cancer Patients: A Large Cohort Retrospective Study. Lung Cancer (Amsterdam Netherlands) (2010) 67(1):114-9. doi: 10.1016/ j.lungcan.2009.03.017

84. He J, Zhi K, Liu G. Predictive Value of Serum Bone Sialoprotein in Patients With Bone Metastasis of Non-Small Cell Lung Cancer. Onkologie (2011) 34 (11):584-8. doi: 10.1159/000334058

85. Fujimoto D, Ueda H, Shimizu R, Kato R, Otoshi T, Kawamura T, et al. Features and Prognostic Impact of Distant Metastasis in Patients With Stage IV Lung Adenocarcinoma Harboring EGFR Mutations: Importance of Bone Metastasis. Clin Exp metastasis (2014) 31(5):543-51. doi: 10.1007/s10585014-9648-3

86. Kuijpers C, Hendriks L, Derks J, Dingemans A, van Lindert A, van den Heuvel M, et al. Association of Molecular Status and Metastatic Organs at Diagnosis in Patients With Stage IV Non-Squamous Non-Small Cell Lung Cancer. Lung Cancer (Amsterdam Netherlands) (2018) 121:76-81. doi: 10.1016/j.lungcan.2018.05.006

87. Hendriks L, Smit E, Vosse B, Mellema W, Heideman D, Bootsma G, et al. EGFR Mutated Non-Small Cell Lung Cancer Patients: More Prone to Development of Bone and Brain Metastases? Lung Cancer (Amsterdam Netherlands) (2014) 84(1):86-91. doi: 10.1016/j.lungcan.2014.01.006

88. Dormieux A, Mezquita L, Cournede P, Remon J, Tazdait M, Lacroix L, et al. Association of Metastatic Pattern and Molecular Status in Stage IV NonSmall Cell Lung Cancer Adenocarcinoma. Eur Radiol (2020) 30(9):5021-8. doi: $10.1007 / \mathrm{s} 00330-020-06784-y$
89. Amelot A, Terrier L, Cristini J, Buffenoir K, Pascal-Moussellard H, Carpentier A, et al. Spinal Metastases From Lung Cancer: Survival Depends Only on Genotype, Neurological and Personal Status, Scarcely of Surgical Resection. Surg Oncol (2020) 34:51-6. doi: 10.1016/ j.suronc.2020.03.005

90. Hong S, Kim Y, Lee J, Kim I, Kim S, Han D, et al. Clinical Characteristics and Continued Epidermal Growth Factor Receptor Tyrosine Kinase Inhibitor Administration in EGFR-Mutated Non-Small Cell Lung Cancer With Skeletal Metastasis. Cancer Res Treat Off J Korean Cancer Assoc (2016) 48 (3):1110-9. doi: 10.4143/crt.2015.289

91. Rosell R, Moran T, Queralt C, Porta R, Cardenal F, Camps C, et al. Screening for Epidermal Growth Factor Receptor Mutations in Lung Cancer. N Engl J Med (2009) 361(10):958-67. doi: 10.1056/NEJMoa0904554

92. Bean J, Brennan C, Shih J, Riely G, Viale A, Wang L, et al. MET Amplification Occurs With or Without T790M Mutations in EGFR Mutant Lung Tumors With Acquired Resistance to Gefitinib or Erlotinib. Proc Natl Acad Sci USA (2007) 104(52):20932-7. doi: 10.1073/ pnas.0710370104

93. Lynch T, Bell D, Sordella R, Gurubhagavatula S, Okimoto R, Brannigan B, et al. Activating Mutations in the Epidermal Growth Factor Receptor Underlying Responsiveness of Non-Small-Cell Lung Cancer to Gefitinib. N Engl J Med (2004) 350(21):2129-39. doi: 10.1056/ NEJMoa040938

94. Kosaka T, Yatabe Y, Endoh H, Yoshida K, Hida T, Tsuboi M, et al. Analysis of Epidermal Growth Factor Receptor Gene Mutation in Patients With NonSmall Cell Lung Cancer and Acquired Resistance to Gefitinib. Clin Cancer Res an Off J Am Assoc Cancer Res (2006) 12(19):5764-9. doi: 10.1158/10780432.CCR-06-0714

95. Balak M, Gong Y, Riely G, Somwar R, Li A, Zakowski M, et al. Novel D761Y and Common Secondary T790M Mutations in Epidermal Growth Factor Receptor-Mutant Lung Adenocarcinomas With Acquired Resistance to Kinase Inhibitors. Clin Cancer Res an Off J Am Assoc Cancer Res (2006) 12(21):6494-501. doi: 10.1158/1078-0432.CCR-06-1570

96. Ettinger D, Wood D, Aggarwal C, Aisner D, Akerley W, Bauman J, et al. NCCN Guidelines Insights: Non-Small Cell Lung Cancer, Version 1.2020. J Natl Compr Cancer Network JNCCN (2019) 17(12):1464-72. doi: 10.6004/ jnccn.2019.0059

97. Mok T, Wu Y-L, Ahn M-J, Garassino M, Kim H, Ramalingam S, et al. Osimertinib or Platinum-Pemetrexed in EGFR T790M-Positive Lung Cancer. N Engl J Med (2017) 376(7):629-40. doi: 10.1056/NEJMoa1612674

98. Ramalingam S, Vansteenkiste J, Planchard D, Cho B, Gray J, Ohe Y, et al. EGFROverall Survival With Osimertinib in Untreated, -Mutated Advanced NSCLC. N Engl J Med (2020) 382(1):41-50. doi: 10.1056/NEJMoa1913662

99. Soria J, Ohe Y, Vansteenkiste J, Reungwetwattana T, Chewaskulyong B, Lee $\mathrm{K}$, et al. Osimertinib in Untreated EGFR-Mutated Advanced Non-Small-Cell Lung Cancer. N Engl J Med (2018) 378(2):113-25. doi: 10.1056/ NEJMoa1713137

100. Oxnard G, Hu Y, Mileham K, Husain H, Costa D, Tracy P, et al. Assessment of Resistance Mechanisms and Clinical Implications in Patients With EGFR T790M-Positive Lung Cancer and Acquired Resistance to Osimertinib. JAMA Oncol (2018) 4(11):1527-34. doi: 10.1001/jamaoncol.2018.2969

101. Zhao S, Li X, Zhao C, Jiang T, Jia Y, Shi J, et al. Loss of T790M Mutation Is Associated With Early Progression to Osimertinib in Chinese Patients With Advanced NSCLC Who Are Harboring EGFR T790M. Lung Cancer (Amsterdam Netherlands) (2019) 128:33-9. doi: 10.1016/j.lungcan. 2018.12.010

102. Yang Z, Yang N, Ou Q, Xiang Y, Jiang T, Wu X, et al. Investigating Novel Resistance Mechanisms to Third-Generation EGFR Tyrosine Kinase Inhibitor Osimertinib in Non-Small Cell Lung Cancer Patients. Clin Cancer Res an Off J Am Assoc Cancer Res (2018) 24(13):3097-107. doi: 10.1158/1078-0432.CCR-17-2310

103. Ou S, Cui J, Schrock A, Goldberg M, Zhu V, Albacker L, et al. Emergence of Novel and Dominant Acquired EGFR Solvent-Front Mutations at Gly796 (G796S/R) Together With C797S/R and L792F/H Mutations in One EGFR (L858R/T790M) NSCLC Patient Who Progressed on Osimertinib. Lung Cancer (Amsterdam Netherlands) (2017) 108:228-31. doi: 10.1016/ j.lungcan.2017.04.003 
104. Bersanelli M, Minari R, Bordi P, Gnetti L, Bozzetti C, Squadrilli A, et al. L718Q Mutation as New Mechanism of Acquired Resistance to AZD9291 in EGFR-Mutated NSCLC. J Thorac Oncol Off Publ Int Assoc Study Lung Cancer (2016) 11(10):e121-3. doi: 10.1016/j.jtho.2016.05.019

105. Aburjania Z, Jang S, Whitt J, Jaskula-Stzul R, Chen H, Rose J. Notch3The Role of in Cancer. Oncologist (2018) 23(8):900-11. doi: 10.1634/ theoncologist.2017-0677

106. KRAS Inhibitor Continues to Impress in NSCLC. Cancer Discov (2020). doi: 10.1158/2159-8290.Cd-nb2020-089

107. Ajona D, Ortiz-Espinosa S, Moreno H, Lozano T, Pajares M, Agorreta J, et al. A Combined PD-1/C5a Blockade Synergistically Protects Against Lung Cancer Growth and Metastasis. Cancer Discov (2017) 7(7):694-703. doi: 10.1158/2159-8290.CD-16-1184

108. Ajona D, Zandueta C, Corrales L, Moreno H, Pajares M, Ortiz-Espinosa S, et al. Blockade of the Complement C5a/C5aR1 Axis Impairs Lung Cancer Bone Metastasis by CXCL16-Mediated Effects. Am J Respir Crit Care Med (2018) 197(9):1164-76. doi: 10.1164/rccm.201703-0660OC

109. Kris M, Johnson B, Berry L, Kwiatkowski D, Iafrate A, Wistuba I, et al. Using Multiplexed Assays of Oncogenic Drivers in Lung Cancers to Select Targeted Drugs. JAMA (2014) 311(19):1998-2006. doi: 10.1001/jama.2014.3741

110. Solomon B, Kim D, Wu Y, Nakagawa K, Mekhail T, Felip E, et al. Final Overall Survival Analysis From a Study Comparing First-Line Crizotinib Versus Chemotherapy in ALK-Mutation-Positive Non-Small-Cell Lung Cancer. J Clin Oncol Off J Am Soc Clin Oncol (2018) 36(22):2251-8. doi: 10.1200/JCO.2017.77.4794

111. Sharma G, Mota I, Mologni L, Patrucco E, Gambacorti-Passerini C, Chiarle R. Tumor Resistance Against ALK Targeted Therapy-Where It Comes From and Where It Goes. Cancers (2018) 10(3). doi: 10.3390/cancers10030062

112. Kim S, Kim T, Kim D, Go H, Keam B, Lee S, et al. Heterogeneity of Genetic Changes Associated With Acquired Crizotinib Resistance in ALKRearranged Lung Cancer. J Thorac Oncol Off Publ Int Assoc Study Lung Cancer (2013) 8(4):415-22. doi: 10.1097/JTO.0b013e318283dcc0

113. Katayama R, Shaw A, Khan T, Mino-Kenudson M, Solomon B, Halmos B, et al. Mechanisms of Acquired Crizotinib Resistance in ALK-Rearranged Lung Cancers. Sci Trans Med (2012) 4(120):120ra17. doi: 10.1126/ scitranslmed.3003316

114. Dogan S, Shen R, Ang D, Johnson M, D'Angelo S, Paik P, et al. Molecular Epidemiology of EGFR and KRAS Mutations in 3,026 Lung Adenocarcinomas: Higher Susceptibility of Women to Smoking-Related KRAS-Mutant Cancers. Clin Cancer Res an Off J Am Assoc Cancer Res (2012) 18(22):6169-77. doi: 10.1158/1078-0432.CCR-11-3265

115. Yu H, Sima C, Shen R, Kass S, Gainor J, Shaw A, et al. Prognostic Impact of KRAS Mutation Subtypes in 677 Patients With Metastatic Lung Adenocarcinomas. J Thorac Oncol Off Publ Int Assoc Study Lung Cancer (2015) 10(3):431-7. doi: 10.1097/JTO.0000000000000432

116. El Osta B, Behera M, Kim S, Berry L, Sica G, Pillai R, et al. Characteristics and Outcomes of Patients With Metastatic KRAS-Mutant Lung Adenocarcinomas: The Lung Cancer Mutation Consortium Experience. J Thorac Oncol Off Publ Int Assoc Study Lung Cancer (2019) 14(5):876-89.

117. Renaud S, Seitlinger J, Falcoz P, Schaeffer M, Voegeli A, Legrain M, et al. Specific KRAS Amino Acid Substitutions and EGFR Mutations Predict SiteSpecific Recurrence and Metastasis Following Non-Small-Cell Lung Cancer Surgery. Br J Cancer (2016) 115(3):346-53. doi: 10.1038/bjc.2016.182

118. Engelman J, Zejnullahu K, Mitsudomi T, Song Y, Hyland C, Park J, et al. MET Amplification Leads to Gefitinib Resistance in Lung Cancer by Activating ERBB3 Signaling. Sci (New York NY) (2007) 316(5827):103943. doi: $10.1126 /$ science. 1141478

119. Pasquini G, Giaccone G. C-MET Inhibitors for Advanced Non-Small Cell Lung Cancer. Expert Opin Investigational Drugs (2018) 27(4):363-75. doi: 10.1080/13543784.2018.1462336

120. Navab R, Liu J, Seiden-Long I, Shih W, Li M, Bandarchi B, et al. CoOverexpression of Met and Hepatocyte Growth Factor Promotes Systemic Metastasis in NCI-H460 Non-Small Cell Lung Carcinoma Cells. Neoplasia (New York NY) (2009) 11(12):1292-300. doi: 10.1593/neo.09622

121. Sterlacci W, Saker S, Huber B, Fiegl M, Tzankov A. Expression of the CXCR4 Ligand SDF-1/CXCL12 Is Prognostically Important for Adenocarcinoma and Large Cell Carcinoma of the Lung. Virchows Archiv an Int J Pathol (2016) 468(4):463-71. doi: 10.1007/s00428-015-1900-y
122. Liao T, Chen W, Sun J, Zhang Y, Hu X, Yang S, et al. CXCR4 Accelerates Osteoclastogenesis Induced by Non-Small Cell Lung Carcinoma Cells Through Self-Potentiation and VCAM1 Secretion. Cell Physiol Biochem Int J Exp Cell Physiol Biochem Pharmacol (2018) 50(3):1084-99. doi: 10.1159/000494533

123. Liu S, Sun H, Zhou J, Jie G, Xie Z, Shao Y, et al. KRAS G12CClinical Characteristics and Prognostic Value of the Mutation in Chinese Non-Small Cell Lung Cancer Patients. Biomark Res (2020) 8:22. doi: 10.1186/s40364020-00199-z

124. Pantsar T. KRAS(G12C)-AMG 510 Interaction Dynamics Revealed by AllAtom Molecular Dynamics Simulations. Sci Rep (2020) 10(1):11992. doi: 10.1038/s41598-020-68950-y

125. Yao G, Zhou Y, Gu Y, Wang Z, Yang M, Sun J, et al. Value of Combining PET/CT and Clinicopathological Features in Predicting EGFR Mutation in Lung Adenocarcinoma With Bone Metastasis. J Cancer (2020) 11(18):55117. doi: $10.7150 /$ jca. 46414

126. Diaz L, Bardelli A. Liquid Biopsies: Genotyping Circulating Tumor DNA. J Clin Oncol Off J Am Soc Clin Oncol (2014) 32(6):579-86. doi: 10.1200/ JCO.2012.45.2011

127. Grano M, Galimi F, Zambonin G, Colucci S, Cottone E, Zallone A, et al Hepatocyte Growth Factor Is a Coupling Factor for Osteoclasts and Osteoblasts In Vitro. Proc Natl Acad Sci USA (1996) 93(15):7644-8. doi: 10.1073/pnas.93.15.7644

128. Whang Y, Jung S, Kim M, Chang I, Park S. Targeting the Hepatocyte Growth Factor and C-Met Signaling Axis in Bone Metastases. Int J Mol Sci (2019) 20 (2). doi: 10.3390/ijms20020384

129. Lee C, Whang Y, Campbell P, Mulcrone P, Elefteriou F, Cho S, et al. Dual Targeting C-Met and VEGFR2 in Osteoblasts Suppresses Growth and Osteolysis of Prostate Cancer Bone Metastasis. Cancer Lett (2018) 414:205-13. doi: 10.1016/j.canlet.2017.11.016

130. Papadimitrakopoulou V, Mok T, Han J, Ahn M, Delmonte A, Ramalingam S, et al. Osimertinib Versus Platinum-Pemetrexed for Patients With EGFR T790M Advanced NSCLC and Progression on a Prior EGFR-Tyrosine Kinase Inhibitor: AURA3 Overall Survival Analysis. Ann Oncol Off J Eur Soc Med Oncol (2020). doi: 10.1016/j.annonc.2020.08.2100

131. Le X, Puri S, Negrao M, Nilsson M, Robichaux J, Boyle T, et al. EGFRLandscape of EGFR-Dependent and -Independent Resistance Mechanisms to Osimertinib and Continuation Therapy Beyond Progression in -Mutant NSCLC. Clin Cancer Res an Off J Am Assoc Cancer Res (2018) 24(24):6195-203. doi: 10.1158/1078-0432.CCR-18-1542

132. Leonetti A, Sharma S, Minari R, Perego P, Giovannetti E, Tiseo M. Resistance Mechanisms to Osimertinib in EGFR-Mutated Non-Small Cell Lung Cancer. Br J Cancer (2019) 121(9):725-37. doi: 10.1038/s41416-019-0573-8

133. Li X, Li R, Zhao L, Liu N, Wang P. Expression of Molecular Factors Correlated With Metastasis in Small Cell Lung Cancer and Their Significance. Int J Clin Exp Pathol (2015) 8(11):14676-84.

134. Burger J, Stewart D, Wald O, Peled A. Potential of CXCR4 Antagonists for the Treatment of Metastatic Lung Cancer. Expert Rev Anticancer Ther (2011) 11(4):621-30. doi: 10.1586/era.11.11

135. Wagner P, Hyjek E, Vazquez M, Meherally D, Liu Y, Chadwick P, et al. CXCL12 and CXCR4 in Adenocarcinoma of the Lung: Association With Metastasis and Survival. J Thorac Cardiovasc Surg (2009) 137(3):615-21. doi 10.1016/j.jtcvs.2008.07.039

136. Spano J, Andre F, Morat L, Sabatier L, Besse B, Combadiere C, et al. Chemokine Receptor CXCR4 and Early-Stage Non-Small Cell Lung Cancer: Pattern of Expression and Correlation With Outcome. Ann Oncol Off J Eur Soc Med Oncol (2004) 15(4):613-7. doi: 10.1093/annonc/mdh136

137. Phillips R, Burdick M, Lutz M, Belperio J, Keane M, Strieter R. The Stromal Derived Factor-1/CXCL12-CXC Chemokine Receptor 4 Biological Axis in Non-Small Cell Lung Cancer Metastases. Am J Respir Crit Care Med (2003) 167(12):1676-86. doi: 10.1164/rccm.200301-071OC

138. Wang L, Wang Z, Liu X, Liu F. High-Level C-X-C Chemokine Receptor Type 4 Expression Correlates With Brain-Specific Metastasis Following Complete Resection of Non-Small Cell Lung Cancer. Oncol Lett (2014) 7(6):1871-6. doi: 10.3892/ol.2014.1979

139. Katsura M, Shoji F, Okamoto T, Shimamatsu S, Hirai F, Toyokawa G, et al. Correlation Between CXCR4/CXCR7/CXCL12 Chemokine Axis Expression and Prognosis in Lymph-Node-Positive Lung Cancer Patients. Cancer Sci (2018) 109(1):154-65. doi: 10.1111/cas.13422 
140. Zhang C, Li J, Han Y, Jiang J. A Meta-Analysis for CXCR4 as a Prognostic Marker and Potential Drug Target in Non-Small Cell Lung Cancer. Drug design Dev Ther (2015) 9:3267-78.

141. Liu K, Bao C, Yao N, Miao C, Varlotto J, Sun Q, et al. Expression of CXCR4 and Non-Small Cell Lung Cancer Prognosis: A Meta-Analysis. Int J Clin Exp Med (2015) 8(5):7435-45.

142. Liang J, Gao W, Liang Y, Zhou X. Chemokine Receptor CXCR4 Expression and Lung Cancer Prognosis: A Meta-Analysis. Int J Clin Exp Med (2015) 8 (4):5163-74

143. Wald O, Shapira O, Izhar U. CXCR4/CXCL12 Axis in Non Small Cell Lung Cancer (NSCLC) Pathologic Roles and Therapeutic Potential. Theranostics (2013) 3(1):26-33. doi: 10.7150/thno.4922

144. Wang Z, Sun J, Feng Y, Tian X, Wang B, Zhou Y, et al. Oncogenic Roles and Drug Target of CXCR4/CXCL12 Axis in Lung Cancer and Cancer Stem Cell. Tumour Biol J Int Soc Oncodevelopmental Biol Med (2016) 37(7):8515-28. doi: 10.1007/s13277-016-5016-Z

145. Walenkamp A, Lapa C, Herrmann K, Wester H. CXCR4 Ligands: The Next Big Hit? J Nucl Med Off publication Soc Nucl Med (2017) 58:77S-82S. doi: 10.2967/jnumed.116.186874

146. Grande F, Giancotti G, Ioele G, Occhiuzzi M, Garofalo A. An Update on Small Molecules Targeting CXCR4 as Starting Points for the Development of Anti-Cancer Therapeutics. Eur J medicinal Chem (2017) 139:519-30. doi: 10.1016/j.ejmech.2017.08.027

147. Peled A, Klein S, Beider K, Burger J, Abraham M. Role of CXCL12 and CXCR4 in the Pathogenesis of Hematological Malignancies. Cytokine (2018) 109:11-6. doi: 10.1016/j.cyto.2018.02.020

148. Salgia R, Stille J, Weaver R, McCleod M, Hamid O, Polzer J, et al. A Randomized Phase II Study of LY2510924 and Carboplatin/Etoposide Versus Carboplatin/Etoposide in Extensive-Disease Small Cell Lung Cancer. Lung Cancer (Amsterdam Netherlands) (2017) 105:7-13. doi: 10.1016/j.lungcan.2016.12.020

149. Bachelerie F, Ben-Baruch A, Burkhardt A, Combadiere C, Farber J, Graham $\mathrm{G}$, et al. International Union of Basic and Clinical Pharmacology. [Corrected]. LXXXIX. Update on the Extended Family of Chemokine Receptors and Introducing a New Nomenclature for Atypical Chemokine Receptors. Pharmacol Rev (2014) 66(1):1-79.

150. Zuo J, Wen M, Li S, Lv X, Wang L, Ai X, et al. Overexpression of CXCR4 Promotes Invasion and Migration of Non-Small Cell Lung Cancer via EGFR and MMP-9. Oncol Lett (2017) 14(6):7513-21. doi: 10.3892/ol.2017.7168

151. Ghosh M, Makena P, Gorantla V, Sinclair S, Waters C. CXCR4 Regulates Migration of Lung Alveolar Epithelial Cells Through Activation of Rac1 and Matrix Metalloproteinase-2. Am J Physiol Lung Cell Mol Physiol (2012) 302 (9):L846-56. doi: 10.1152/ajplung.00321.2011

152. Huang Y, Hsiao Y, Chen Y, Wei Y, Lai T, Tang C. Stromal Cell-Derived Factor-1 Enhances Motility and Integrin Up-Regulation Through CXCR4, ERK and NF-kappaB-Dependent Pathway in Human Lung Cancer Cells. Biochem Pharmacol (2007) 74(12):1702-12. doi: 10.1016/ j.bcp.2007.08.025

153. Wald O. CXCR4 Based Therapeutics for Non-Small Cell Lung Cancer (NSCLC). J Clin Med (2018) 7(10). doi: 10.3390/jcm7100303

154. Jung K, Heishi T, Incio J, Huang Y, Beech E, Pinter M, et al. Targeting CXCR4-Dependent Immunosuppressive Ly6C Monocytes Improves Antiangiogenic Therapy in Colorectal Cancer. Proc Natl Acad Sci USA (2017) 114(39):10455-60. doi: 10.1073/pnas.1710754114

155. Chen Y, Ramjiawan R, Reiberger T, Ng M, Hato T, Huang Y, et al. CXCR4 Inhibition in Tumor Microenvironment Facilitates Anti-Programmed Death Receptor-1 Immunotherapy in Sorafenib-Treated Hepatocellular Carcinoma in Mice. Hepatol (Baltimore Md.) (2015) 61(5):1591-602. doi: 10.1002/ hep. 27665

156. Vadrevu S, Chintala N, Sharma S, Sharma P, Cleveland C, Riediger L, et al. Complement C5a Receptor Facilitates Cancer Metastasis by Altering T-Cell Responses in the Metastatic Niche. Cancer Res (2014) 74(13):3454-65. doi: 10.1158/0008-5472.CAN-14-0157

157. Kleczko E, Kwak J, Schenk E, Nemenoff R. Targeting the Complement Pathway as a Therapeutic Strategy in Lung Cancer. Front Immunol (2019) 10:954. doi: 10.3389/fimmu.2019.00954

158. Dang T, Eichenberger S, Gonzalez A, Olson S, Carbone D. Constitutive Activation of Notch3 Inhibits Terminal Epithelial Differentiation in Lungs of
Transgenic Mice. Oncogene (2003) 22(13):1988-97. doi: 10.1038/ sj.onc. 1206230

159. Shi C, Qian J, Ma M, Zhang Y, Han B. Notch 3 Protein, Not Its Gene Polymorphism, Is Associated With the Chemotherapy Response and Prognosis of Advanced NSCLC Patients. Cell Physiol Biochem Int J Exp Cell Physiol Biochem Pharmacol (2014) 34(3):743-52. doi: 10.1159/ 000363039

160. Xiong J, Zhang X, Chen X, Wei Y, Lu D, Han Y, et al. Prognostic Roles of mRNA Expression of Notch Receptors in Non-Small Cell Lung Cancer. Oncotarget (2017) 8(8):13157-65. doi: 10.18632/oncotarget.14483

161. Konishi J, Kawaguchi K, Vo H, Haruki N, Gonzalez A, Carbone D, et al. Gamma-Secretase Inhibitor Prevents Notch3 Activation and Reduces Proliferation in Human Lung Cancers. Cancer Res (2007) 67(17):8051-7. doi: 10.1158/0008-5472.CAN-07-1022

162. Hassan W, Yoshida R, Kudoh S, Motooka Y, Ito T. Evaluation of Role of Notch3 Signaling Pathway in Human Lung Cancer Cells. J Cancer Res Clin Oncol (2016) 142(5):981-93. doi: 10.1007/s00432-016-2117-4

163. Li C, Song G, Zhang S, Wang E, Cui Z. Wnt3a Increases the Metastatic Potential of Non-Small Cell Lung Cancer Cells In Vitro in Part via Its Upregulation of Notch3. Oncol Rep (2015) 33(3):1207-14. doi: 10.3892/ or.2014.3700

164. Liu L, Chen X, Wang Y, Qu Z, Lu Q, Zhao J, et al. Notch3 Is Important for TGF- $\beta$-Induced Epithelial-Mesenchymal Transition in Non-Small Cell Lung Cancer Bone Metastasis by Regulating ZEB-1. Cancer Gene Ther (2014) 21 (9):364-72. doi: 10.1038/cgt.2014.39

165. Haruki N, Kawaguchi K, Eichenberger S, Massion P, Olson S, Gonzalez A, et al. Dominant-Negative Notch3 Receptor Inhibits Mitogen-Activated Protein Kinase Pathway and the Growth of Human Lung Cancers. Cancer Res (2005) 65(9):3555-61. doi: 10.1158/0008-5472.CAN-04-3132

166. Ha H, Lee W, Park H, Lee S, Lee J, Chung M. Clinical Significance of CXCL16/CXCR6 Expression in Patients With Prostate Cancer. Mol Med Rep (2011) 4(3):419-24.

167. Na K, Kim H, Jung W, Sung J, Kalil R, Kim Y, et al. CXCL16 and CXCR6 in Ewing Sarcoma Family Tumor. Hum Pathol (2014) 45(4):753-60. doi: 10.1016/j.humpath.2013.09.017

168. Bieniasz M, Oszajca K, Eusebio M, Kordiak J, Bartkowiak J, Szemraj J. The Positive Correlation Between Gene Expression of the Two Angiogenic Factors: VEGF and BMP-2 in Lung Cancer Patients. Lung Cancer (Amsterdam Netherlands) (2009) 66(3):319-26. doi: 10.1016/j.lungcan. 2009.02.020

169. Choi Y, Kim S, Park K, Oh S, Seo J, Shin S, et al. The Serum Bone Morphogenetic Protein-2 Level in Non-Small-Cell Lung Cancer Patients. Med Oncol (Northwood London England) (2012) 29(2):582-8. doi: 10.1007/ s12032-011-9852-9

170. Fei Z, Yao C, Yang X, Huang X, Ma S. Serum BMP-2 Up-Regulation as an Indicator of Poor Survival in Advanced Non-Small Cell Lung Cancer Patients. Asian Pacific J Cancer Prev APJCP (2013) 14(9):5293-9. doi: 10.7314/APJCP.2013.14.9.5293

171. Huang F, Cao Y, Wu G, Chen J, Wang C, Lin W, et al. BMP2 Signalling Activation Enhances Bone Metastases of Non-Small Cell Lung Cancer. J Cell Mol Med (2020). doi: 10.21203/rs.2.18934/vl

172. Diez-Fraile A, Lammens T, Benoit Y, D'Herde K. The Calcium-Sensing Receptor as a Regulator of Cellular Fate in Normal and Pathological Conditions. Curr Mol Med (2013) 13(2):282-95. doi: 10.2174/ 156652413804810763

173. Spence M, Hui R, Chang J, Schottinger J, Millares M, Rashid N. Treatment Patterns and Overall Survival Associated With First-Line Systemic Therapy for Patients With Advanced Non-Small Cell Lung Cancer. J managed Care specialty Pharm (2017) 23(2):195-205. doi: 10.18553/jmcp.2017.23.2.195

174. Liu L, Fan Y, Chen Z, Zhang Y, Yu J. CaSR Induces Osteoclast Differentiation and Promotes Bone Metastasis in Lung Adenocarcinoma. Front Oncol (2020) 10:305. doi: 10.3389 /fonc. 2020.00305

175. Kim W, Takyar F, Swan K, Jeong J, VanHouten J, Sullivan C, et al. CalciumSensing Receptor Promotes Breast Cancer by Stimulating Intracrine Actions of Parathyroid Hormone-Related Protein. Cancer Res (2016) 76(18):534860. doi: 10.1158/0008-5472.CAN-15-2614

176. Yi C, Wang Y, Zhang C, Xuan Y, Zhao S, Liu T, et al. Cleavage and Polyadenylation Specific Factor 4 Targets NF-kb/Cyclooxygenase-2 
Signaling to Promote Lung Cancer Growth and Progression. Cancer Lett (2016) 381(1):1-13.

177. Wu X, Wang Y, Huang R, Gai Q, Liu H, Shi M, et al. SOSTDC1-Producing Follicular Helper T Cells Promote Regulatory Follicular T Cell Differentiation. Sci (New York NY) (2020) 369(6506):984-8. doi: 10.1126/ science.aba6652

178. Liu L, Wu S, Yang Y, Cai J, Zhu X, Wu J, et al. SOSTDC1 Is Down-Regulated in Non-Small Cell Lung Cancer and Contributes to Cancer Cell Proliferation. Cell Biosci (2016) 6:24. doi: 10.1186/s13578-016-0091-9

179. Chen G, Gong H, Wang T, Wang J, Han Z, Bai G, et al. SOSTDC1 Inhibits Bone Metastasis in Non-Small Cell Lung Cancer and may Serve as a Clinical Therapeutic Target. Int J Mol Med (2018) 42(6):3424-36. doi: 10.3892/ ijmm.2018.3926

180. Sánchez-Tena S, Cubillos-Rojas M, Schneider T, Rosa J. Functional and Pathological Relevance of HERC Family Proteins: A Decade Later. Cell Mol Life Sci CMLS (2016) 73(10):1955-68. doi: 10.1007/s00018-016-2139-8

181. Wrage M, Hagmann W, Kemming D, Uzunoglu F, Riethdorf S, Effenberger $\mathrm{K}$, et al. Identification of HERC5 and Its Potential Role in NSCLC Progression. Int J Cancer (2015) 136(10):2264-72. doi: 10.1002/ijc.29298

182. Holdenrieder S, Wehnl B, Hettwer K, Simon K, Uhlig S, Dayyani F. Carcinoembryonic Antigen and Cytokeratin-19 Fragments for Assessment of Therapy Response in Non-Small Cell Lung Cancer: A Systematic Review and Meta-Analysis. Br J Cancer (2017) 116(8):1037-45. doi: 10.1038/ bjc. 2017.45

183. Konigsberg W, Kirchhofer D, Riederer M, Nemerson Y. The TF:VIIa Complex: Clinical Significance, Structure-Function Relationships and Its Role in Signaling and Metastasis. Thromb Haemostasis (2001) 86(3):757-71. doi: 10.1055/s-0037-1616129

184. Han X, Zha H, Yang F, Guo B, Zhu B. Tumor-Derived Tissue Factor Aberrantly Activates Complement and Facilitates Lung Tumor Progression via Recruitment of Myeloid-Derived Suppressor Cells. Int J Mol Sci (2017) 18 (1). doi: 10.3390/ijms 18010022

185. Xia Q, Zhang X, Chen Q, Chen X, Teng J, Wang C, et al. Down-Regulation of Tissue Factor Inhibits Invasion and Metastasis of Non-Small Cell Lung Cancer. J Cancer (2020) 11(5):1195-202. doi: 10.7150/jca.37321

186. Chin R, Chen K, Usmani A, Chua C, Harris P, Binkley M, et al. Detection of Solid Tumor Molecular Residual Disease (MRD) Using Circulating Tumor DNA (ctDNA). Mol diagnosis Ther (2019) 23(3):311-31. doi: 10.1007/ s40291-019-00390-5

187. Jahr S, Hentze H, Englisch S, Hardt D, Fackelmayer F, Hesch R, et al. DNA Fragments in the Blood Plasma of Cancer Patients: Quantitations and Evidence for Their Origin From Apoptotic and Necrotic Cells. Cancer Res (2001) 61(4):1659-65.

188. Chaudhuri A, Chabon J, Lovejoy A, Newman A, Stehr H, Azad T, et al. Early Detection of Molecular Residual Disease in Localized Lung Cancer by Circulating Tumor DNA Profiling. Cancer Discov (2017) 7(12):1394-403. doi: 10.1158/2159-8290.CD-17-0716

189. Yao W, Mei C, Nan X, Hui L. Evaluation and Comparison of In Vitro Degradation Kinetics of DNA in Serum, Urine and Saliva: A Qualitative Study. Gene (2016) 590(1):142-8. doi: 10.1016/j.gene.2016.06.033

190. Leighl N, Page R, Raymond V, Daniel D, Divers S, Reckamp K, et al. Clinical Utility of Comprehensive Cell-Free DNA Analysis to Identify Genomic Biomarkers in Patients With Newly Diagnosed Metastatic Non-Small Cell Lung Cancer. Clin Cancer Res an Off J Am Assoc Cancer Res (2019) 25 (15):4691-700. doi: 10.1158/1078-0432.CCR-19-0624

191. Pécuchet N, Zonta E, Didelot A, Combe P, Thibault C, Gibault L, et al. BasePosition Error Rate Analysis of Next-Generation Sequencing Applied to Circulating Tumor DNA in Non-Small Cell Lung Cancer: A Prospective Study. PloS Med (2016) 13(12):e1002199.

192. Ye Y, Luo Z, Shi D. Use of Cell Free DNA as a Prognostic Biomarker in NonSmall Cell Lung Cancer Patients With Bone Metastasis. Int J Biol Markers (2019) 34(4):381-8. doi: 10.1177/1724600819854452

193. Jia J, Huang B, Zhuang Z, Chen S. Circulating Tumor DNA as Prognostic Markers for Late Stage NSCLC With Bone Metastasis. Int J Biol Markers (2018) 33(2):222-30. doi: 10.1177/1724600817753576

194. Jin P, Gou B, Qian W. Urinary Markers in Treatment Monitoring of Lung Cancer Patients With Bone Metastasis. Int J Biol Markers (2019) 34(3):24350. doi: $10.1177 / 1724600819848762$
195. Mok T, Wu Y, Lee J, Yu C, Sriuranpong V, Sandoval-Tan J, et al. Detection and Dynamic Changes of EGFR Mutations From Circulating Tumor DNA as a Predictor of Survival Outcomes in NSCLC Patients Treated With First-Line Intercalated Erlotinib and Chemotherapy. Clin Cancer Res an Off J Am Assoc Cancer Res (2015) 21(14):3196-203. doi: 10.1158/1078-0432.CCR-14-2594

196. Kim C, Shim H, Hong M, Cha Y, Heo S, Park H, et al. Detection of Activating and Acquired Resistant Mutation in Plasma From EGFR-Mutated NSCLC Patients by Peptide Nucleic Acid (PNA) Clamping-Assisted Fluorescence Melting Curve Analysis. Oncotarget (2017) 8(39):65111-22. doi: 10.18632/ oncotarget.17786

197. Johann D, Steliga M, Shin I, Yoon D, Arnaoutakis K, Hutchins L, et al. Liquid Biopsy and Its Role in an Advanced Clinical Trial for Lung Cancer. Exp Biol Med (Maywood N.J.) (2018) 243(3):262-71. doi: 10.1177/1535370217750087

198. Lee Y, Park S, Kim W, Lee J, Jang S, Choi J, et al. Correlation Between Progression-Free Survival, Tumor Burden, and Circulating Tumor DNA in the Initial Diagnosis of Advanced-Stage EGFR-Mutated Non-Small Cell Lung Cancer. Thorac Cancer (2018) 9(9):1104-10. doi: 10.1111/17597714.12793

199. Diao Z, Han Y, Zhang R, Li J. Circulating Tumour DNA: A New Biomarker to Monitor Resistance in NSCLC Patients Treated With EGFR-TKIs. Biochim Biophys Acta Rev Cancer (2020) 1873(2):188363. doi: 10.1016/ j.bbcan.2020.188363

200. Ponting C, Oliver P, Reik W. Evolution and Functions of Long Noncoding RNAs. Cell (2009) 136(4):629-41. doi: 10.1016/j.cell.2009.02.006

201. Zhang Z, Peng Z, Cao J, Wang J, Hao Y, Song K, et al. Long Noncoding RNA PXN-AS1-L Promotes Non-Small Cell Lung Cancer Progression via Regulating PXN. Cancer Cell Int (2019) 19:20. doi: 10.1186/s12935-0190734-0

202. Zhang Y, Li Y, Han L, Zhang P, Sun S. SUMO1P3 Is Associated Clinical Progression and Facilitates Cell Migration and Invasion Through Regulating miR-136 in Non-Small Cell Lung Cancer. Biomed Pharmacotherapy = Biomed Pharmacotherapie (2019) 113:108686. doi: 10.1016/j.biopha. 2019.108686

203. Liu M, Sun W, Liu Y, Dong X. The Role of lncRNA MALAT1 in Bone Metastasis in Patients With Non-Small Cell Lung Cancer. Oncol Rep (2016) 36(3):1679-85. doi: 10.3892/or.2016.4909

204. Li N, Wang Y, Liu X, Luo P, Jing W, Zhu M, et al. Identification of Circulating Long Noncoding RNA HOTAIR as a Novel Biomarker for Diagnosis and Monitoring of Non-Small Cell Lung Cancer. Technol Cancer Res Treat (2017) 16(6):1060-6. doi: 10.1177/1533034617723754

205. Pandey M, Mukhopadhyay A, Sharawat S, Kumar S. Role of microRNAs in Regulating Cell Proliferation, Metastasis and Chemoresistance and Their Applications as Cancer Biomarkers in Small Cell Lung Cancer. Biochim Biophys Acta Rev Cancer (2021) 1876(1):188552.

206. Liu J, Luo R, Wang J, Luan X, Wu D, Chen H, et al. Viatumor Cell-Derived Exosomal miR-770 Inhibits M2 Macrophage Polarization Targeting MAP3K1 to Inhibit the Invasion of Non-Small Cell Lung Cancer Cells. Front Cell Dev Biol (2021) 9:679658. doi: 10.3389/fcell.2021.679658

207. Tan X, Tong L, Li L, Xu J, Xie S, Ji L, et al. Loss of Smad4 Promotes Aggressive Lung Cancer Metastasis by De-Repression of PAK3 via miRNA Regulation. Nat Commun (2021) 12(1):4853.

208. Zhu X, Kudo M, Huang X, Sui H, Tian H, Croce C, et al. Frontiers of MicroRNA Signature in Non-Small Cell Lung Cancer. Front Cell Dev Biol (2021) 9:643942. doi: 10.3389/fcell.2021.643942

209. Kim E, Kim J, Lee S, Lee H, Yoon J, Hong J, et al. QKI, a miR-200 Target Gene, Suppresses Epithelial-to-Mesenchymal Transition and Tumor Growth. Int J Cancer (2019) 145(6):1585-95. doi: 10.1002/ijc.32372

210. Spolverini A, Fuchs G, Bublik D, Oren M. Let-7b and Let-7c microRNAs Promote Histone H2B Ubiquitylation and Inhibit Cell Migration by Targeting Multiple Components of the H2B Deubiquitylation Machinery. Oncogene (2017) 36(42):5819-28. doi: 10.1038/onc.2017.187

211. Wang R, Xu J, Xu J, Zhu W, Qiu T, Li J, et al. MiR-326/Sp1/KLF3: A Novel Regulatory Axis in Lung Cancer Progression. Cell Proliferation (2019) 52(2): e12551. doi: 10.1111/cpr.12551

212. Zhou W, Wu Y, Pan M, Liu D, Liu B. Proliferation and Migration of Lung Cancer Could be Inhibited by Oxymatrine Through the Regulation for miR520/VEGF. Am J Chin Med (2019) 47(4):865-78. doi: 10.1142/ S0192415X19500459 
213. Baumgartner U, Berger F, Hashemi Gheinani A, Burgener S, Monastyrskaya K, Vassella E. miR-19b Enhances Proliferation and Apoptosis Resistance via the EGFR Signaling Pathway by Targeting PP2A and BIM in Non-Small Cell Lung Cancer. Mol Cancer (2018) 17(1):44. doi: 10.1186/s12943-018-0781-5

214. Huang X, Xiao S, Zhu X, Yu Y, Cao M, Zhang X, et al. miR-196b-5pMediated Downregulation of FAS Promotes NSCLC Progression by Activating IL6-STAT3 Signaling. Cell Death Dis (2020) 11(9):785. doi: 10.1038/s41419-020-02997-7

215. Jeon Y, Kim T, Park D, Nuovo G, Rhee S, Joshi P, et al. miRNA-Mediated TUSC3 Deficiency Enhances UPR and ERAD to Promote Metastatic Potential of NSCLC. Nat Commun (2018) 9(1):5110. doi: 10.1038/s41467018-07561-8

216. Liang G, Meng W, Huang X, Zhu W, Yin C, Wang C, et al. miR-196b-5pMediated Downregulation of TSPAN12 and GATA6 Promotes Tumor Progression in Non-Small Cell Lung Cancer. Proc Natl Acad Sci USA (2020) 117(8):4347-57. doi: 10.1073/pnas.1917531117

217. Wan J, Yang X, Ren Y, Li X, Zhu Y, Haddock A, et al. Inhibition of miR-155 Reduces Impaired Autophagy and Improves Prognosis in an Experimental Pancreatitis Mouse Model. Cell Death Dis (2019) 10(4):303. doi: 10.1038/ s41419-019-1545-x

218. Wei F, Ma C, Zhou T, Dong X, Luo Q, Geng L, et al. Exosomes Derived From Gemcitabine-Resistant Cells Transfer Malignant Phenotypic Traits via Delivery of miRNA-222-3p. Mol Cancer (2017) 16(1):132. doi: 10.1186/ s12943-017-0694-8

219. Zhou H, Feng B, Abudoureyimu M, Lai Y, Lin X, Tian C, et al. The Functional Role of Long Non-Coding RNAs and Their Underlying Mechanisms in Drug Resistance of Non-Small Cell Lung Cancer. Life Sci (2020) 261:118362. doi: 10.1016/j.lfs.2020.118362

220. Ma G, Zhu J, Liu F, Yang Y. Long Noncoding RNA LINC00460 Promotes the Gefitinib Resistance of Nonsmall Cell Lung Cancer Through Epidermal Growth Factor Receptor by Sponging miR-769-5p. DNA Cell Biol (2019) 38 (2):176-83. doi: 10.1089/dna.2018.4462

221. Fang Z, Chen W, Yuan Z, Liu X, Jiang H. LncRNA-MALAT1 Contributes to the Cisplatin-Resistance of Lung Cancer by Upregulating MRP1 and MDR1 via STAT3 Activation. Biomed Pharmacotherapy = Biomed Pharmacotherapie (2018) 101:536-42. doi: 10.1016/j.biopha.2018.02.130
222. Ji L, Liu X, Zhang S, Tang S, Yang S, Li S, et al. The Novel Triazolonaphthalimide Derivative LSS-11 Synergizes the Anti-Proliferative Effect of Paclitaxel via STAT3-Dependent MDR1 and MRP1 Downregulation in Chemoresistant Lung Cancer Cells. Molecules (Basel Switzerland) (2017) 22(11). doi: 10.3390/molecules 22111822

223. Taverna S, Giusti I, D'Ascenzo S, Pizzorno L, Dolo V. Breast Cancer Derived Extracellular Vesicles in Bone Metastasis Induction and Their Clinical Implications as Biomarkers. Int J Mol Sci (2020) 21(10). doi: 10.3390/ ijms21103573

224. Kuo C, Lee M, Tsai M, Yang C, Hung J, Chong I. EGFRThe Factors Predicting Concordant Epidermal Growth Factor Receptor (EGFR) Mutation Detected in Liquid/Tissue Biopsy and the Related Clinical Outcomes in Patients of Advanced Lung Adenocarcinoma With Mutations. J Clin Med (2019) 8(11). doi: 10.3390/jcm8111758

225. Ikeda S, Schwaederle M, Mohindra M, Fontes Jardim D, Kurzrock R. MET Alterations Detected in Blood-Derived Circulating Tumor DNA Correlate With Bone Metastases and Poor Prognosis. J Hematol Oncol (2018) 11(1):76. doi: $10.1186 /$ s13045-018-0610-8

Conflict of Interest: The authors declare that the research was conducted in the absence of any commercial or financial relationships that could be construed as a potential conflict of interest.

Publisher's Note: All claims expressed in this article are solely those of the authors and do not necessarily represent those of their affiliated organizations, or those of the publisher, the editors and the reviewers. Any product that may be evaluated in this article, or claim that may be made by its manufacturer, is not guaranteed or endorsed by the publisher.

Copyright (c) 2021 Chai, Yinwang, Wang, Wang, Xue, Li, Zhou, Zhang, Wang, Zhang, Li, Mou, Sun, Qu, Wang, Zhang, Chen and Ye. This is an open-access article distributed under the terms of the Creative Commons Attribution License (CC BY). The use, distribution or reproduction in other forums is permitted, provided the original author(s) and the copyright owner(s) are credited and that the original publication in this journal is cited, in accordance with accepted academic practice. No use, distribution or reproduction is permitted which does not comply with these terms. 